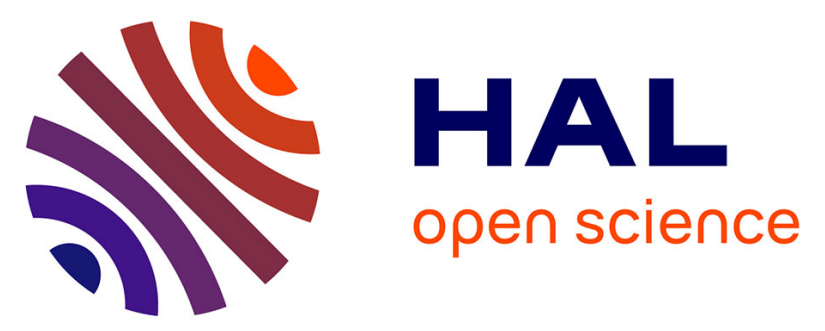

\title{
Supramolecular Anchoring of NCN-Pincer Palladium Complexes into a $\beta$-Barrel Protein Host: Molecular-Docking and Reactivity Insights
}

Lucrèce Pocquet, Nikolay Vologdin, Giuseppe Felice Mangiatordi, Ilaria Ciofini, Orazio Nicolotti, Serge Thorimbert, Michèle Salmain

\section{To cite this version:}

Lucrèce Pocquet, Nikolay Vologdin, Giuseppe Felice Mangiatordi, Ilaria Ciofini, Orazio Nicolotti, et al.. Supramolecular Anchoring of NCN-Pincer Palladium Complexes into a $\beta$-Barrel Protein Host: Molecular-Docking and Reactivity Insights. European Journal of Inorganic Chemistry, 2017, 2017 (30), pp.3622-3634. 10.1002/ejic.201700365 . hal-01585231

\section{HAL Id: hal-01585231 \\ https://hal.sorbonne-universite.fr/hal-01585231}

Submitted on 11 Sep 2017

HAL is a multi-disciplinary open access archive for the deposit and dissemination of scientific research documents, whether they are published or not. The documents may come from teaching and research institutions in France or abroad, or from public or private research centers.
L'archive ouverte pluridisciplinaire HAL, est destinée au dépôt et à la diffusion de documents scientifiques de niveau recherche, publiés ou non, émanant des établissements d'enseignement et de recherche français ou étrangers, des laboratoires publics ou privés. 


\section{Supramolecular anchoring of NCN-pincer palladium complexes into a $\beta$-barrel protein host. Molecular docking and reactivity insights}

Lucrèce Pocquet, ${ }^{a}$ Nikolay Vologdin, ${ }^{a}$ Giuseppe Felice Mangiatordi, ${ }^{c}$ Ilaria Ciofini, ${ }^{b}$ Orazio Nicolotti, ${ }^{c, d}$ Serge Thorimberta, ${ }^{\mathrm{a}}$, Michèle Salmain, ${ }^{\mathrm{a}, *}$

a Sorbonne Universités, UPMC Univ Paris 06, CNRS, Institut Parisien de Chimie Moléculaire (IPCM), 4 Place Jussieu, F-75005 Paris, France

b PSL Research university, Chimie ParisTech, CNRS Institut de Recherche de Chimie Paris (IRCP), 11 rue Pierre et Marie Curie F-75005 Paris, France

c Dipartimento di Farmacia - Scienze del Farmaco, Via Orabona, 4, Università di Bari "Aldo Moro", Bari, Italy

d Centro Ricerche TIRES, Università di Bari “Aldo Moro”, Via Amendola 173, I-70126 Bari, Italy

* To whom correspondence should be sent. Email: serge.thorimbert@upmc.fr or Michele.salmain@upmc.fr ; homepage: http://www.ipcm.fr/presentation-682

The three first authors contributed equally to the work

\section{Abstract}

Several prochiral NCN pincer complexes of palladium(II) including hemilabile ligands and a long aliphatic chain were synthesized and characterized spectroscopically. In some of the complexes, the presence of two different substituents on the $\mathrm{N}$ donor atoms made them stereogenic so that they were isolated as a mixture of diastereoisomers, which could be differentiated by ${ }^{1} \mathrm{H}$ NMR. Binding of some of these complexes to bovine $\beta$-lactoglobin by insertion within its inner cavity was theoretically investigated by molecular docking simulations and experimentally confirmed by CD spectroscopy. Adjunction of H-bond donor substituents on the ligand framework gave more stable supramolecular protein - complex assemblies. These constructs were shown to catalyze aldol condensation reactions in aqueous medium affording in some cases the less favorable cis-product. Since the corresponding complexes gave exclusively the trans product in the absence of $\beta$-lactoglobulin, this unusual diastereoselectivity was ensued by the second sphere of coordination brought by the protein host. 


\section{Keywords}

Palladium; $\beta$-lactoglobulin; docking; aldol reaction; metalloenzymes

\section{Introduction}

The concept of artificial metalloenzymes has emerged to fill the gap between metal- and enzyme-based catalytic transformations.[1] Pioneered by Wilson and Whitesides in $1978^{[2]}$, it is a rapidly developing and highly promising field of research. By definition, artificial metalloenzymes are hybrid constructs containing a catalytically active transition metal complex incorporated within a biomacromolecular host, typically a protein, peptide or DNA via covalent, dative or supramolecular binding. ${ }^{[3]}$ Such constructs are meant to combine the typical advantages of both enzymatic and (organo)metallic catalysts, such as high turnovers of biocatalysts and wide substrate scope of metal catalysts and at the same time to overcome some of the limitations of both systems. ${ }^{[4]}$ To date, artificial metalloenzymes have been designed to catalyze asymmetric (transfer) hydrogenation of ketones and imines ${ }^{[5]}$, epoxidation, ${ }^{[6]}$, sulfoxidation, ${ }^{[7]}$ as well as an increasing range of abiotic reactions such as $\mathrm{C}-\mathrm{H}$ bond activation, ${ }^{[8]}$ Michael additions, ${ }^{[9]}$ Diels-Alder reactions ${ }^{[9 b, 10]}$ and so on.

The rational design of artificial metalloenzymes is a very challenging task because of the difficulty to identify effective complementarities between a given metal complex and the biological host. In this scenario, molecular docking, a well-known computational method commonly employed in drug design can be useful to predict the most likely conformations (poses) of a given ligand in a protein binding site, as well as for estimating the strength of the interaction between both partners. Based on a benchmark study, Robles et al. recently showed that such a computational technique could efficiently be adapted to the design of artificial metalloenzymes, foreseeing an increased use of this approach in the near future.[11]

In the classical hybrid construct approach, the metal and its surrounding achiral ligands (the first coordination sphere) are responsible for the catalytic activity while the protein scaffold, including the aminoacid residues at a short range from the metal center (the second coordination sphere), is responsible for driving the selectivity by favoring a single orientation of the substrate in the protein binding site (Scheme 1).[12] Herein we introduce a new approach called "dormant chirality" where the metal is coordinated by 
prochiral hemi-labile ligands. In this approach, the local 3D protein arrangement may force the synthetic metal cofactor to adopt a single stereoconfiguration so as to minimize steric / electronic repulsions within the host protein (Scheme 1).

Scheme 1. The classical and "dormant chirality" approaches in the design of artificial metalloenzymes

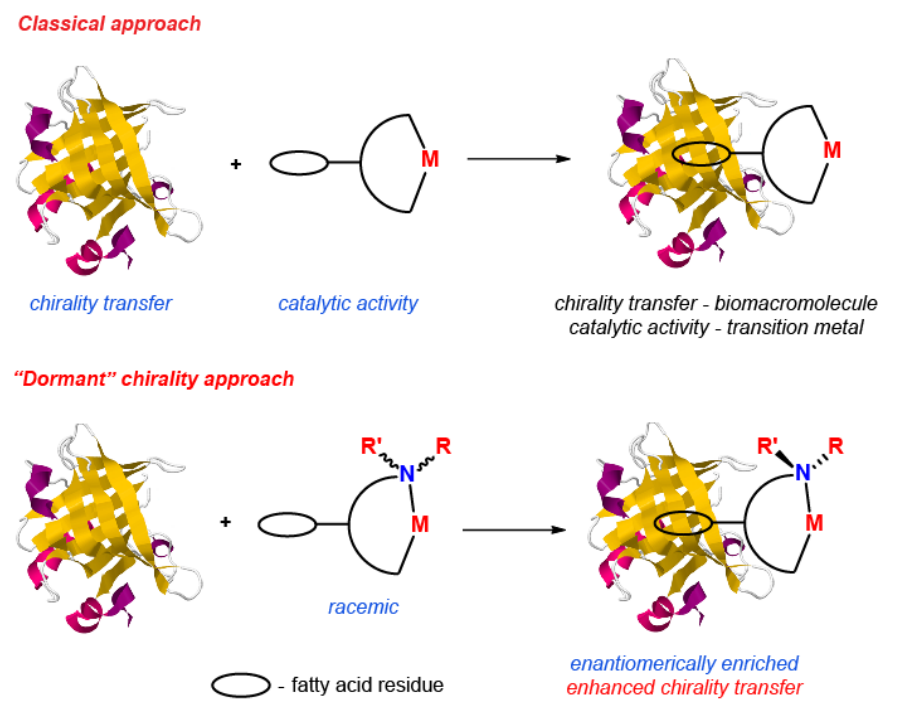

This could in turn bring the chiral center(s) closer to the substrate and eventually enhance the enantioselectivity of the catalyzed reaction. As a proof-of-concept, we chose the $\beta$-lactoglobulin ( $\beta$-LG) / fatty acid supramolecular assembly from which we previously built up artificial transfer hydrogenases with promising activity and selectivity in the reduction of a prochiral ketone.[13] Palladium(II) complexes of prochiral hemi-labile NCN pincer ligands carrying a fatty acid side chain were synthesized and characterized spectroscopically. In addition, binding of the new complexes to $\beta$-LG was investigated by circular dichroism (CD) spectroscopy and molecular docking simulations were performed to predict the most probable orientation of the synthetic metal cofactors within the $\beta$-LG binding site and validate the "dormant chirality" concept. Finally, the catalytic activity of the supramolecular constructs was examined on model aldol condensation reactions.

\section{Results and discussion}

Synthesis of palladium(II) pincer complexes of fatty acids and study of their structural properties

Several strategies have been devised to incorporate palladium(II) entities into proteins. The first one reported by Van Koten and coll. consisted in the site-specific and covalent 
anchoring of ECE pincer Pd(II) complexes to the enzyme cutinase by reaction of the active site serine residue. ${ }^{[14]}$ A similar route was applied to convert a lipase into an enzyme catalyzing Heck coupling reactions. ${ }^{[15]}$ Covalent anchoring of a monophosphine to a cysteine residue of the PYP protein, followed by treatment with $[\mathrm{Pd}(\text { allyl }) \mathrm{Cl}]_{2}$ afforded a metalloenzyme that catalyzed an allylic amination reaction.[16] Dative assembling of (allyl)Pd(II) complex to apo-ferritin afforded a heavily metallated protein that catalyzed a Suzuki coupling reaction with good turnover.[17] Supramolecular anchoring of biotinylated phosphine Pd(II) complexes to (strept)avidin afforded hybrid enzymes that catalyzed allylic alkylation or Suzuki cross-coupling reaction with high conversion and enantiomeric excess.[18]

As recalled above, $\beta$-LG is an attractive protein host for the construction of artificial metalloenzymes by supramolecular anchoring because of its high affinity for fatty acids with more than 12 carbons chain length. On the other hand, palladium complexes of NCN pincer ligands are water- and air-tolerant and display versatile catalytic properties.[19] Therefore, we underwent to synthesize NCN-pincer ligands for which an aliphatic chain of 11,15 or 17 carbons was appended to the aromatic ring. The general synthetic route is depicted in Scheme 2.

Commercially available 5-aminoisophthalic acid $\mathbf{1}$ was esterified and subsequently reduced by $\mathrm{LiAlH}_{4}$ to afford (5-amino-1,3-phenylene)dimethanol 3 in good yield.[20] Acylation of the amino group of $\mathbf{3}$ was carried out to introduce the aliphatic chains. To append the 11-carbon substituent, 3 was allowed to react with lauric acid in the presence of HOBT and EDCI to yield 4a. Introduction of the stearyl chain was achieved by reaction of stearoyl chloride to yield $\mathbf{4 c}$. Attempts to prepare compound $\mathbf{4 b}$ by reaction of palmitic acid in the presence of DCC or EDCI were unsuccessful or gave poor yields. So acylation was finally achieved by reaction of 1-palmitoyl-1H-1,2,3benzotriazole prepared on the side. ${ }^{[21]}$ Treatment of compounds 4 a-c with $\mathrm{HBr}$ gave the dibromides 5a-c which were readily converted into the pincer ligands 6aa'-cc' by reaction with the corresponding secondary amines (a': HN(Me $)_{2} ; b^{\prime}$ : HNMeEt; c': HNEtBn). 
Scheme 2. i) $\mathrm{SOCl}_{2}$, EtOH, 6h, reflux; ii) $\mathrm{LiAlH}_{4}$, THF, reflux 4 h then overnight at rt; iii) lauric acid, $\mathrm{BtOH}, \mathrm{EDCI}, \mathrm{THF} / \mathrm{DMF}, 0^{\circ} \mathrm{C}$ then reflux $24 \mathrm{~h}$; iv) stearoyl chloride, $\mathrm{NaHCO}_{3}$, THF, reflux 16 h; v) 1-palmitoyl-1H-1,2,3-benzotriazole, THF, 48 h reflux; vi) $\mathrm{HBr} / \mathrm{AcOH}$ (33\%) overnight, rt; vii) $\mathrm{R}_{2} \mathrm{R}_{3} \mathrm{NH}, \mathrm{K}_{2} \mathrm{CO}_{3}, \mathrm{MeCN}$, reflux overnight<smiles>CCOC(=O)c1cc(N)cc(C(=O)OCC)c1</smiles><smiles>Nc1cc(CO)cc(CO)c1</smiles><smiles>[R]C(=O)Nc1cc(CN([R5])[R5])cc(CN([R5])[R5])c1</smiles><smiles>CC(C)(C)C1(C)CCCCC1</smiles>

6aa' $\mathrm{R}_{1}=\mathrm{C}_{11} \mathrm{H}_{23}, \mathrm{R}_{2}=\mathrm{R}_{3}=$ Me, quantitative 6ba' $\mathrm{R}_{1}=\mathrm{C}_{15} \mathrm{H}_{31}, \mathrm{R}_{2}=\mathrm{R}_{3}=\mathrm{Me}, 71 \%$

6b'' $\mathrm{R}_{1}=\mathrm{C}_{15} \mathrm{H}_{31}, \mathrm{R}_{2}=\mathrm{Me}, \mathrm{R}_{3}=\mathrm{Et}, 55 \%$

6bc' $R_{1}=\mathrm{C}_{15} \mathrm{H}_{31}, \mathrm{R}_{2}=\mathrm{Et}, \mathrm{R}_{3}=\mathrm{Bn}, 77 \%$

6ca' $\mathrm{R}_{1}=\mathrm{C}_{17} \mathrm{H}_{35}, \mathrm{R}_{2}=\mathrm{R}_{3}=\mathrm{Me}$, quantitative

6ad' $\mathrm{R}_{1}=\mathrm{C}_{11} \mathrm{H}_{23}, \mathrm{R}_{2}=\mathrm{CH}_{2} \mathrm{CH}_{2} \mathrm{OH}, \mathrm{R}_{3}=\mathrm{Me}, 99 \%$

6bd' $\mathrm{R}_{1}=\mathrm{C}_{15} \mathrm{H}_{31}, \mathrm{R}_{2}=\mathrm{CH}_{2} \mathrm{CH}_{2} \mathrm{OH}, \mathrm{R}_{3}=\mathrm{Me}, 87 \%$

6cd' $\mathrm{R}_{1}=\mathrm{C}_{17} \mathrm{H}_{35}, \mathrm{R}_{2}=\mathrm{CH}_{2} \mathrm{CH}_{2} \mathrm{OH}, \mathrm{R}_{3}=\mathrm{Me}, 78 \%$

Attempts to directly metallate the pincer ligands with $\mathrm{Pd}(\mathrm{OAc})_{2}$ or $\left[(\mathrm{PhCN}) \mathrm{PdCl}_{2}\right]$ were unsuccessful or gave poor yields. Alternatively, silylation of compound 6aa' by reaction of $\mathrm{n}$-BuLi followed by $\mathrm{Me}_{3} \mathrm{SiOTf}$ under the conditions reported in the literature[22] afforded a mixture of mono- and di-silylated products. So palladation of selected pincer ligands was done in 2 steps by transmetallation of organomercury intermediates (Scheme 3).[23]

Scheme 3. i) $\mathrm{Hg}(\mathrm{OAc})_{2}$, EtOH, reflux then $\mathrm{LiCl}$, EtOH reflux15 min; ii) $\mathrm{Pd}(\mathrm{OAc})_{2}$, $\mathrm{DCM} / \mathrm{MeOH}$, overnight, rt then $\mathrm{LiCl}, \mathrm{MeOH}, 1 \mathrm{~h}, \mathrm{rt}$ 


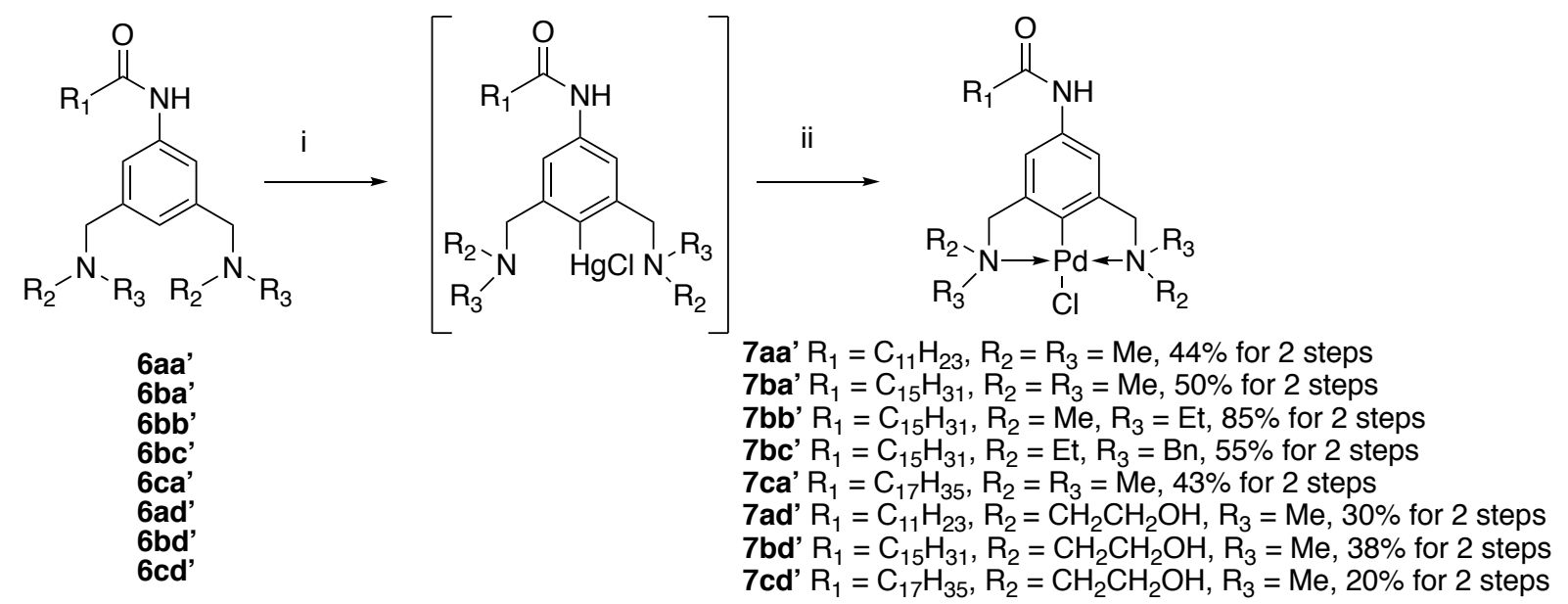

Treatment of the ligands with $\mathrm{Hg}(\mathrm{OAc})_{2}$ afforded the mercurated derivatives that underwent a transmetallation reaction with $\mathrm{Pd}(\mathrm{OAc})_{2}$ to give the Pd-pincer complexes 7aa', 7ba', 7bb', 7bc' and 7ca' in moderate yield.

Formation of the palladium complexes 7aa'-7ca' was evidenced by the disappearance of the signal of the aromatic proton in para-position of the amide and upfield shift of 0.4 ppm of the 2 protons in ortho-position. In contrast, the methyl and benzylic protons of 7aa'-7ca' underwent a downfield shift of 0.7 and $0.5 \mathrm{ppm}$, respectively. In the ${ }^{13} \mathrm{C}$ NMR, the signals of methyl and benzylic carbons also underwent a downfield shift of 8 and 12 ppm, respectively and the signal of the quaternary carbon coordinating Pd appeared at $151.0 \mathrm{ppm}$.

Compounds 7bb' and 7bc' displayed more complex ${ }^{1} \mathrm{H}$ NMR spectra owing to the presence of stereogenic centers on the two nitrogen atoms. Coordination of palladium blocks nitrogen inversion and leads to the formation of a mixture of three stereoisomers $\left(\mathrm{S}_{\mathrm{N}}, \mathrm{S}_{\mathrm{N}}\right),\left(\mathrm{R}_{\mathrm{N}}, \mathrm{R}_{\mathrm{N}}\right)$ and $\left(\mathrm{S}_{\mathrm{N}}, \mathrm{R}_{\mathrm{N}}\right)$ (Scheme 4$)$. Variable temperature NMR study was carried out in order to study the possible exchange between stereoisomers. On the ${ }^{1} \mathrm{H}$ NMR spectrum of $\mathbf{7} \mathbf{b b}$ ' in $\mathrm{CDCl}_{3}$ at $300 \mathrm{~K}$, two sets of sharp signals (4 doublets for the benzylic protons, two singlets for the $\mathrm{NCH}_{3}$ protons, four doublets of quartets for $\mathrm{NCH}_{2} \mathrm{CH}_{3}$ protons and two triplets for the $\mathrm{NCH}_{2} \mathrm{CH}_{3}$ protons) were observed, in agreement with the presence of cis and trans isomers with respect to the coordination plane. The integral values gave a diastereomeric ratio of 56:44, which was not influenced by change of temperature. Decreasing the temperature to $263 \mathrm{~K}$ as well as slight heating to $313 \mathrm{~K}$ did not induce significant changes in the proton NMR spectrum, which indicates slow exchange or its absence. On the other hand, in DMSO- $d^{6}$ the signals were broad. 
Increasing the temperature caused a decrease of $\Delta \sigma$ between corresponding signals of stereoisomers. For the benzylic protons, coalescence was observed at 363K (Fig. 1a). A similar behavior was observed for compound $\mathbf{7} \mathbf{b c}^{\prime}$ with a diastereomeric ratio of 61:39 at $300 \mathrm{~K}$. At $353 \mathrm{~K}$, the diastereomeric ratio became $56: 44$ and a change of $\Delta \sigma$ of $7-18 \mathrm{~Hz}$ and no coalescence was observed (Fig. 1b).

\section{Scheme 4}

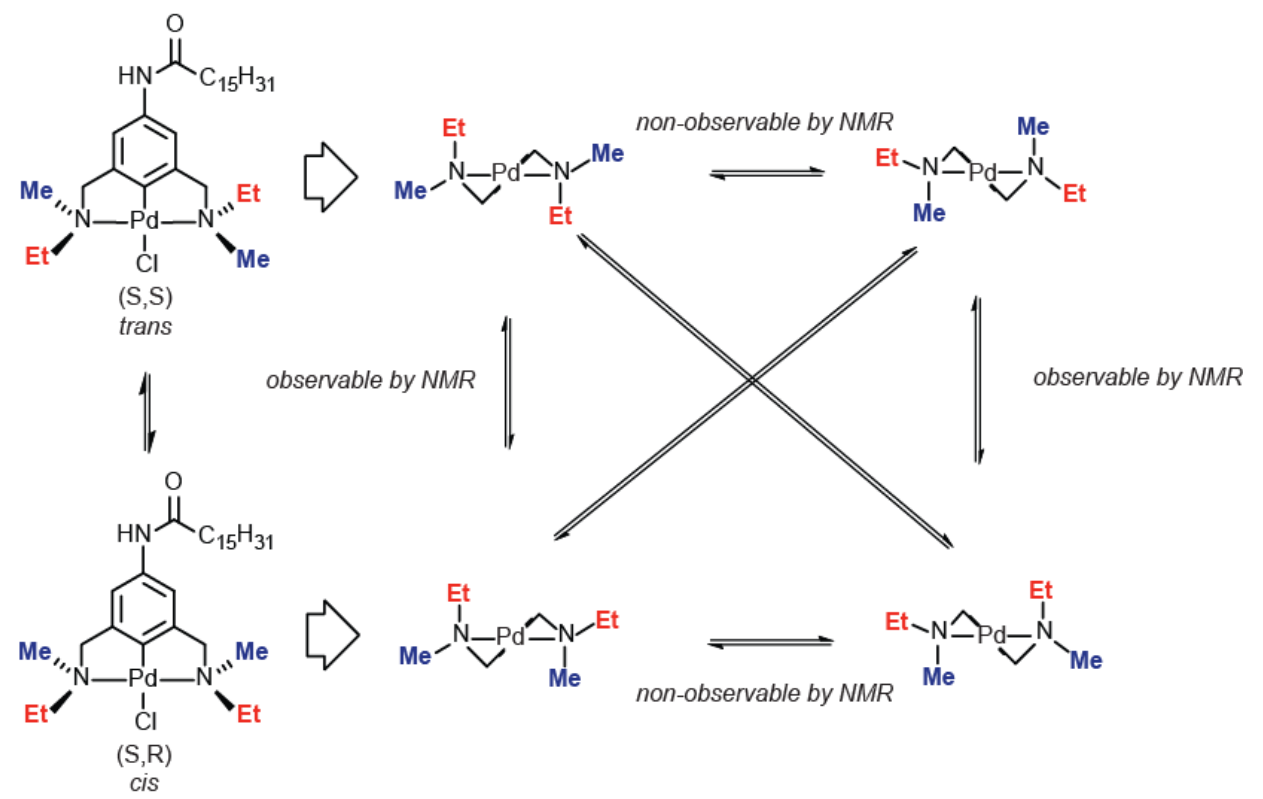

Spectral analysis allowed to estimate the Gibbs free energy of major-minor isomer exchange to $63.3 \mathrm{~kJ} / \mathrm{mol}$ at $300 \mathrm{~K}$ for $\mathbf{7} \mathbf{b b}^{\prime}$ and $61.6 \mathrm{~kJ} / \mathrm{mol}$ at $300 \mathrm{~K}$ for $\mathbf{7} \mathbf{b c}^{\prime}$, which matches values of similar complexes. ${ }^{[24]}$ This study showed that the cis/trans exchange occurs in solution; it is relatively slow and could be observed by ${ }^{1} \mathrm{H} N \mathrm{NR}$, in contrast to chelate ring conformational exchange. ${ }^{[25]}$ It should also be noted that the rate of this exchange increased with the temperature and in the presence of coordinating solvents, which could be explained by the exchange mechanism depicted in Scheme 5.[24]

Figure 1. Temperature-dependent ${ }^{1} \mathrm{H}$ NMR spectra of $\mathbf{7} \mathbf{b b}^{\prime}(\mathrm{a})$ and $\mathbf{7} \mathbf{b} \mathbf{c}^{\prime}(\mathrm{b})$ in DMSO-d ${ }^{6}$ 
(a)

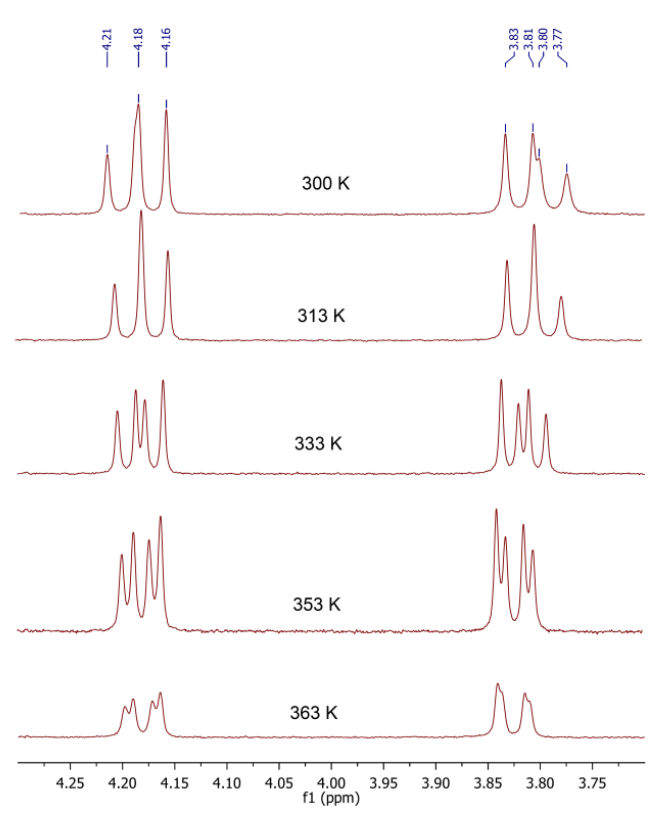

(b)

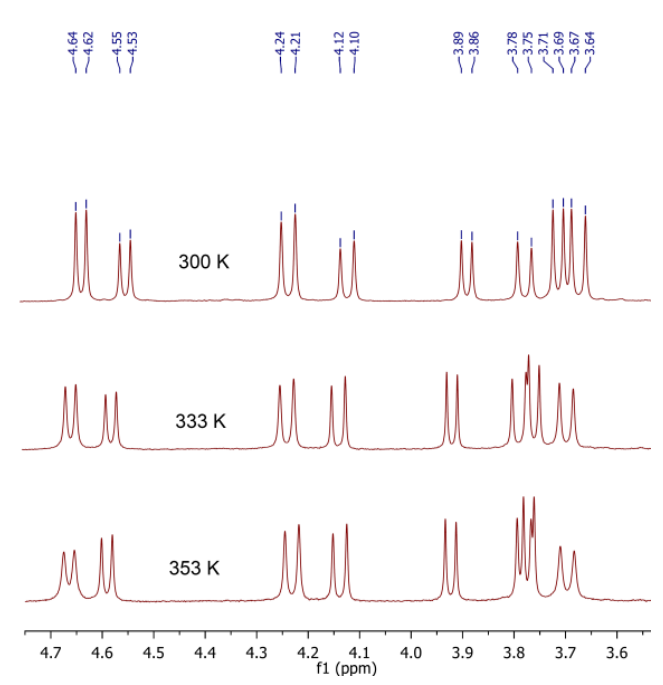

Scheme 5. Possible mechanism for cis/trans isomerization of complexes $\mathbf{7} \mathbf{b b}^{\prime}$ and $\mathbf{7} \mathbf{b c} \mathbf{c}^{\mathbf{\prime}}$ in coordinating solvent $\mathrm{L}$

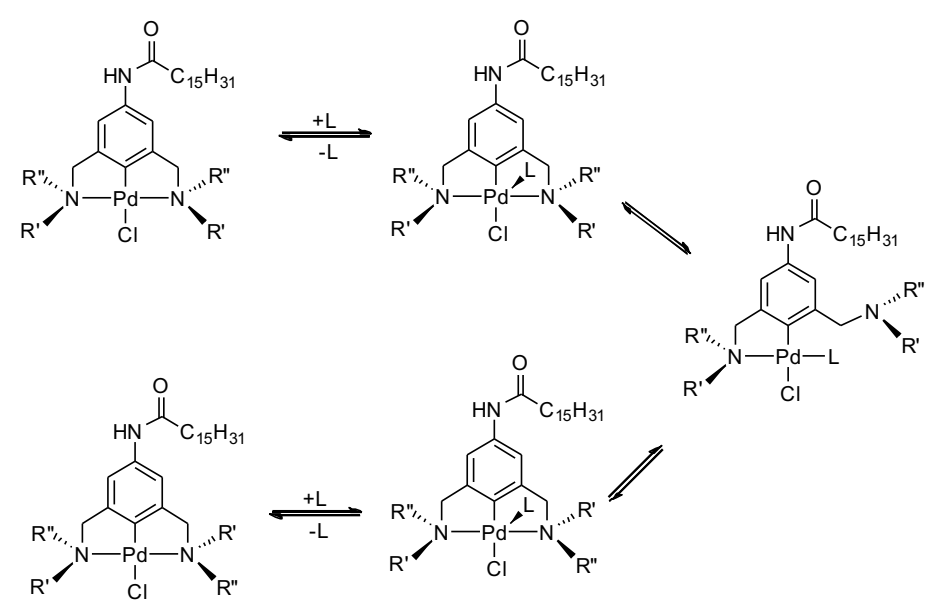

Binding studies of ligands and palladium pincer complexes to $\beta$-LG by circular dichroism spectroscopy

Beta-lactogloblin ( $\beta$-LG) is a member of the lipocalin family that displays a $\beta$-barrel tertiary structure made of 8 antiparallel $\beta$-strands. The cavity generated by this folding can host various hydrophobic ligands, including fatty acids. ${ }^{[26]}$ We previously took advantage of this feature to incorporate half-sandwich dipyridylamine $\mathrm{Rh}^{\mathrm{III}}$ complexes within $\beta$-LG, which conferred transfer hydrogenase properties to this protein.[13]

The near-uv circular dichroism (CD) spectrum of $\beta$-LG displays a pattern of negative bands between 250 and $310 \mathrm{~nm}$ assigned to its aromatic residues.[27] Binding of a 
chromophore to $\beta$-LG may induce a change of the CD spectrum caused by its presence in the chiral environment of the protein (extrinsic effect) or by perturbation of the environment of the aromatic residues (intrinsic effect).[28] Unfortunately, insignificant change of the near-uv CD spectrum of the protein was noticed upon addition of 1 eq. ligands 6aa' - 6ca' to $\beta$-LG in phosphate buffer pH 7.5 (Fig. S1a). The same experiment was carried out with some of the Pd complexes. As for the ligands, no significant change of the CD spectrum was observed (not shown). Therefore, a displacement experiment was carried out as follows. The CD spectrum of a stoichiometric mixture of $\beta$-LG and $N, N$-dipyridin-2-hexadecanamide (Ref) whose insertion within the $\beta$-LG cavity was previously asserted by CD spectroscopy ${ }^{[13 b]}$ was first recorded. A broad positive band centered at $270 \mathrm{~nm}$ was observed on the CD spectrum of the mixture of $\beta$-LG and Ref. Upon addition of a stoichiometric amount of $\mathbf{7} \mathbf{b a}^{\prime}$ and $\mathbf{7} \mathbf{b} \mathbf{b}^{\prime}$ derived from palmitic acid, the intensity of the positive band was shown to decrease significantly as a result from partial displacement of Ref by the Pd complexes from the $\beta$-LG cavity (fig. 2). In contrast, the CD spectrum of the mixture of $\beta-L G$, Ref and $\mathbf{7} \mathbf{b c}$ ' became very noisy as a result of 7bc' insolubility in the buffer. Thus, near-uv CD spectroscopy provided an indirect and qualitative evidence of the ability of the Pd complexes 7 $\mathbf{7 b a}$ ' and $\mathbf{7} \mathbf{b b}$ ' derived from palmitic acid to bind to $\beta$-LG by probable insertion within the hydrophobic binding pocket of the protein ("calyx"). The far-uv CD spectrum of $\beta$-LG displayed a broad negative band centered around $215 \mathrm{~nm}$ (fig. S1b) typical of $\beta$-sheet proteins. Addition of a stoichiometric amount of $\mathbf{7} \mathbf{b a}^{\prime}, \mathbf{7} \mathbf{b b}^{\prime}$ or $\mathbf{7} \mathbf{b} \mathbf{c}^{\prime}$ to the protein solution induced no change of the spectrum, indicating that the secondary structure was maintained upon binding of 7ba' and 7bb'.

Figure 2. Near-uv CD spectra of $\beta$-LG (dotted black line), $\beta$-LG + Ref (gray line) and $\beta$-LG + Ref + Pd complex (black line) in 20 mM phosphate buffer pH 7.5. Left: 7ba'; Middle: 7bc'; Right: 7bb' 


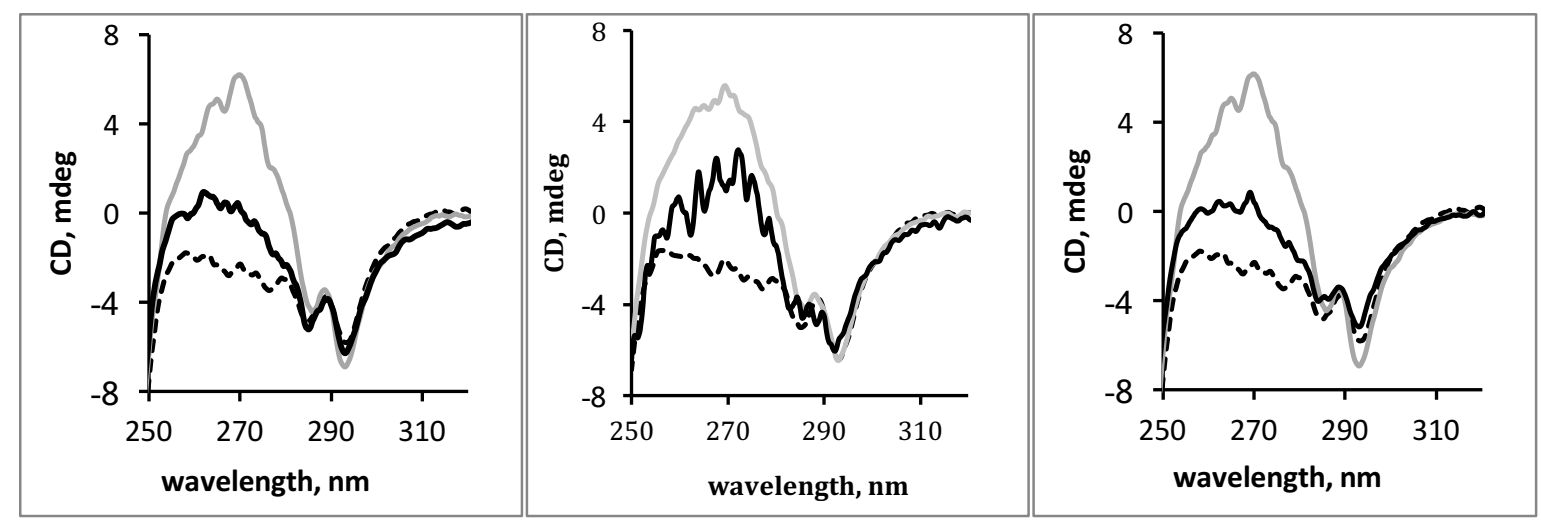

\section{Docking studies}

The top scoring poses obtained for compounds $\mathbf{7} \mathbf{b a}^{\prime}-\mathbf{7} \mathbf{7} \mathbf{c}^{\prime}$ are shown in Fig. 3. As mentioned above, these compounds are characterized by an aliphatic chain of 15 carbon atoms, an organometallic "head" with the metal and its coordination sphere, and an amide group linking the aliphatic chain to the organometallic head. Gratifyingly, all the poses show the aliphatic chain inside the calyx, as expected. In addition, 7ba' as well as all the diastereoisomers of $\mathbf{7} \mathbf{b} \mathbf{b}^{\prime}$ establish an H-bond interaction with the backbone of Asp85. Such interactions involve the nitrogen atom of the backbone. As far as $\mathbf{7} \mathbf{b c}$ ' is concerned, the only diastereoisomer establishing an H-bond interaction with the protein is $\mathbf{7} \mathbf{b c}^{\prime}\left(\mathbf{S}_{\mathbf{N}}, \mathbf{R}_{\mathbf{N}}\right)$ while no H-bond can be detected by the top scoring poses of $\mathbf{7} \mathbf{b c} \mathbf{c}^{\prime}\left(\mathbf{R}_{\mathbf{N}}, \mathbf{R}_{\mathbf{N}}\right)$ and $\mathbf{7} \mathbf{b c} \mathbf{c}^{\prime}\left(\mathbf{S}_{\mathrm{N}}, \mathbf{S}_{\mathrm{N}}\right)$. This evidence offers a glimpse of a possible explanation for the inability of $\mathbf{7} \mathbf{b c}^{\prime}$ to bind to the protein. Indeed, we can speculate that the presence of bulky substituents on the metallic head prevents the formation of an $\mathrm{H}$-bond interaction between the ligand and the protein, the occurrence of orientated interactions of its amide group being forbidden. As already mentioned, the docking posing is related to the preferred conformation adopted for binding, while the scoring represents a rough energetic estimation of the strength of the established interactions, based on the application of relatively simple molecular mechanics equations. 
Figure 3. Top scoring docking poses of $\mathbf{7} \mathbf{b a}, \mathbf{7} \mathbf{7} \mathbf{b} \mathbf{b}^{\prime}, \mathbf{7} \mathbf{\mathbf { b }} \mathbf{c}$ ' and $\mathbf{7} \mathbf{b d}$. Ligands and important residues are rendered as sticks while protein is shown as a surface. H-bond interactions are depicted by a dotted line. For the sake of clarity, only the polar hydrogen atoms are displayed.
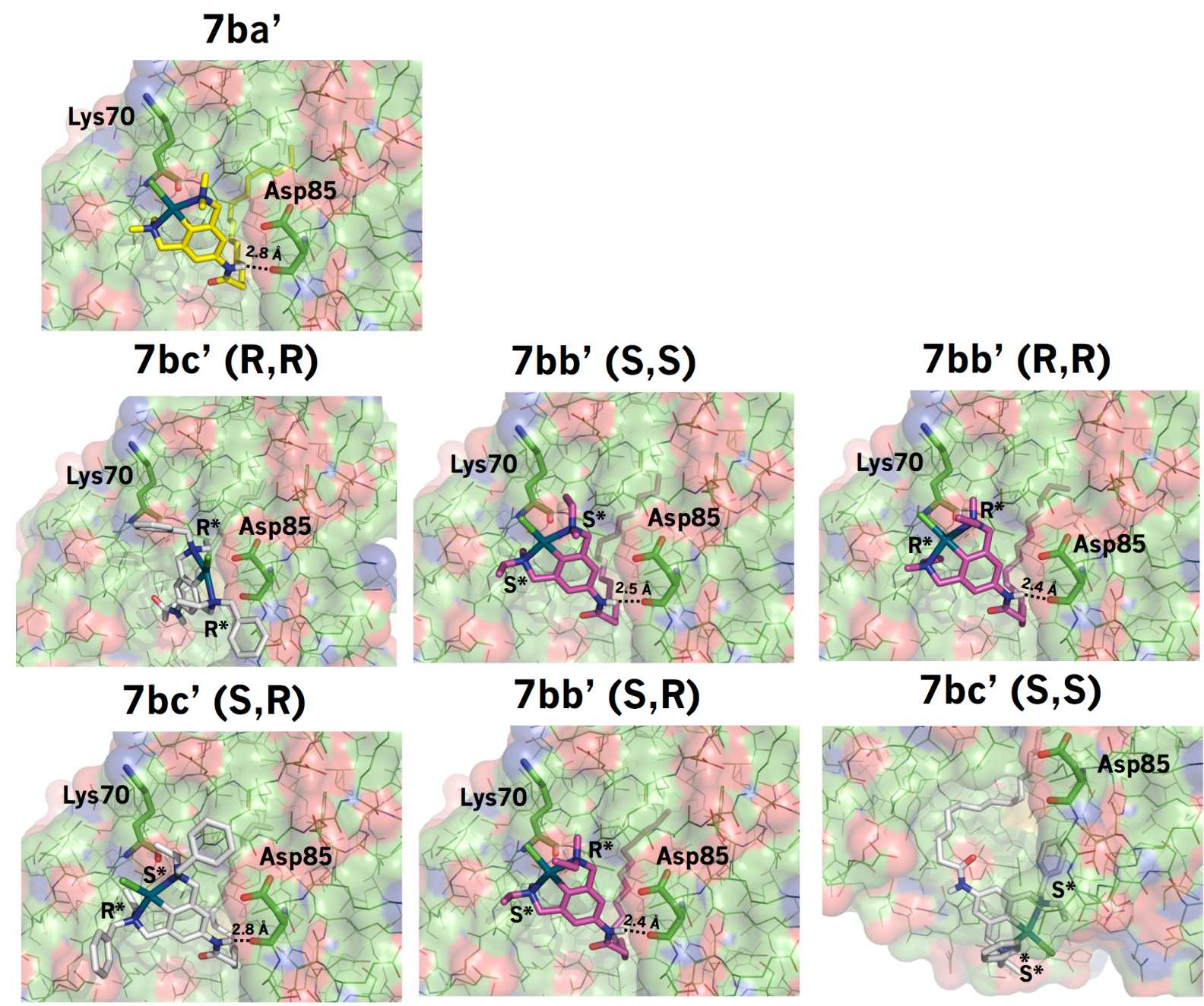

\section{$7 b^{\prime}(S, S)$}

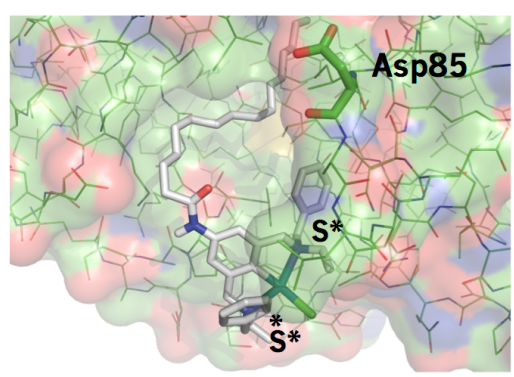

\section{7bd' (S,R)}

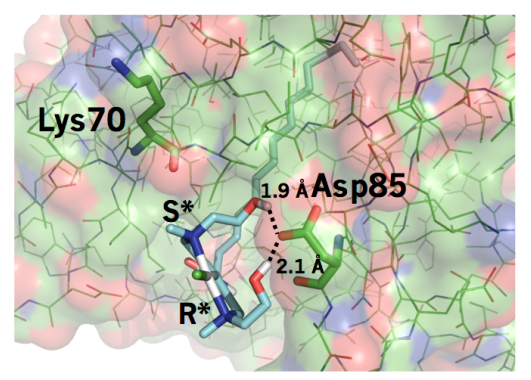

\section{7bd' (S,S)}

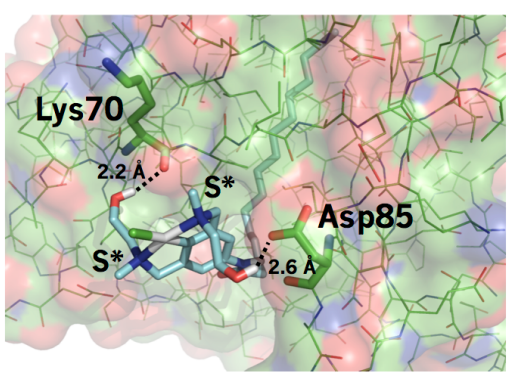

\section{7bd' (R,R)}

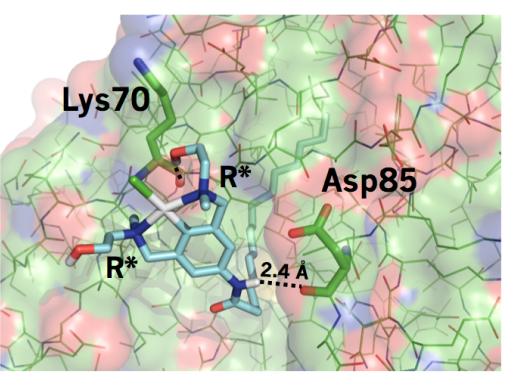

In this respect, it is acknowledged that the main drawback of docking simulations is the accuracy in the estimation of binding energy. This is the sum of a number of different energetics terms normally awarding larger sized ligands being intrinsically capable of establishing more interactions, especially the hydrophobic ones, which are dominant in determining protein-ligand affinity. ${ }^{[29]}$ Based on this evidence, it would be misleading to 
estimate the compounds binding on the sole basis of docking scores when large difference in size occurs. In this respect, it is important to notice that, although larger, 7bc' gives the worst docking scores whatever stereoisomer is considered, $(-8.10$ $\mathrm{kcal} / \mathrm{mol}$ for $\mathbf{7} \mathbf{b c} \mathbf{c}^{\prime}\left(\mathbf{S}_{\mathrm{N}}, \mathbf{R}_{\mathbf{N}}\right),-7.80 \mathrm{kcal} / \mathrm{mol}$ for $\mathbf{7} \mathbf{b} \mathbf{c}^{\prime}\left(\mathbf{R}_{\mathbf{N}}, \mathbf{R}_{\mathbf{N}}\right)$ and $-7.65 \mathrm{kcal} / \mathrm{mol}$ for $\mathbf{7} \mathbf{b c} \mathbf{c}^{\prime}$ $\left(\mathbf{S}_{\mathrm{N}}, \mathbf{S}_{\mathrm{N}}\right)$ to be compared to $\mathbf{7} \mathbf{b a}^{\prime}(-8.16 \mathrm{kcal} / \mathrm{mol})$ and $\mathbf{7} \mathbf{b b}^{\prime}\left(-8.57 \mathrm{kcal} / \mathrm{mol}\right.$ for $\mathbf{7} \mathbf{b b}^{\prime}$ $\left(\mathbf{S}_{\mathrm{N}}, \mathbf{R}_{\mathbf{N}}\right)$, -8.44 kcal/mol for $\mathbf{7} \mathbf{b b}^{\prime}\left(\mathbf{S}_{\mathrm{N}}, \mathbf{S}_{\mathrm{N}}\right)$ and $-8.33 \mathrm{kcal} / \mathrm{mol}$ for $\mathbf{7} \mathbf{b b}^{\prime}\left(\mathbf{S}_{\mathrm{N}}, \mathbf{S}_{\mathrm{N}}\right)$. In other words, both posing and scoring would indicate that binding of $\mathbf{7} \mathbf{b c}^{\prime}$ to $\beta$-LG is less favorable than 7ba' and 7bb', in agreement with the experimental results. Correlatively, the relative position of the organometallic head of $\mathbf{7} \mathbf{b} \mathbf{a}^{\prime}$ and the 3 diastereomers of $\mathbf{7} \mathbf{b} \mathbf{b}^{\prime}$ within the protein host was identical as illustrated in fig. 3, indicating that the ethyl substituent on the nitrogen atoms was not discriminant enough to favor a given stereoconfiguration.

It is worth to note that the organometallic heads of all the considered ligands do not establish any strong interaction with the protein residues, thus suggesting the presence of different conformations after the formation of the protein-ligand complex. This is in full agreement with the electron density map derived from X-ray diffraction of a similar metal-complex bound to $\beta$-LG (PDB code 4KII).[30] However, the visual inspection of the obtained poses indicates the presence of polar and charged residues potentially able to establish strong $\mathrm{H}$-bond interactions with $\mathrm{H}$-bond acceptors or donors carried by the organometallic head. Examples are represented by the side chain of Asp85 and Lys70, both very close to the organometallic head of the top scoring pose of $\mathbf{7} \mathbf{b a}$ '. Based on these observations, a large chemical library of palladium pincer complexes with different H-bond acceptors and donors bound to the organometallic head was screened. From this in silico investigation, compound 7bd' carrying a hydroxyethyl group on the $\mathrm{N}$ atoms was predicted to display higher affinity for the protein host thanks to additional H-bond interactions. This is evident in Fig. 3 where the top scoring poses of all the diastereomers of $\mathbf{7} \mathbf{b d}$ ' are shown. Indeed, the presence of hydroxyethyl groups bound to the organometallic head allows establishing strong H-bond interactions with the side chains of Asp85 (all the 7bd' diastereomers) and Lys70 ( $\mathbf{7 b d}\left(\mathbf{S}_{\mathbf{N}}, \mathbf{S}_{\mathbf{N}}\right)$ and $\mathbf{7 b d}\left(\mathbf{R}_{\mathbf{N}}, \mathbf{R}_{\mathbf{N}}\right)$ ). The importance of such interactions is again supported by the obtained docking scores. Indeed, $\mathbf{7 b d}\left(\mathbf{S}_{\mathbf{N}}, \mathbf{R}_{\mathbf{N}}\right)$, $\mathbf{7} \mathbf{b d}\left(\mathbf{S}_{\mathrm{N}}, \mathbf{S}_{\mathrm{N}}\right)$ and $\mathbf{7} \mathbf{b d}$ ' $\left(\mathbf{R}_{\mathbf{N}}, \mathbf{R}_{\mathbf{N}}\right)$ provide better docking scores with respect to all the other investigated compounds, being equal to $-10.20 \mathrm{kcal} / \mathrm{mol},-9.60$ 
$\mathrm{kcal} / \mathrm{mol}$ and $-8.80 \mathrm{kcal} / \mathrm{mol}$ respectively. Conversely to $\mathbf{7} \mathbf{b b}$ ', the relative position of the organometallic head was this time dependent of the diastereomer so that it may later influence the outcome of the catalyzed reaction.

Therefore, complexes 7ad' - 7cd' were synthesized according to the general route depicted in Schemes 2 and 3. The presence of stereogenic centers on the two nitrogen atoms made the benzylic as well as the hydroxyethyl protons diastereotopic. Long distance coupling between the aromatic protons and one of the benzylic protons was also observed. The occurrence of stereoisomers in solution was deduced from the presence of two singlets for the N-Me protons of 7ad' - 7cd'.

Binding of 7ad' - 7 cd' to $\beta$-LG was subsequently studied by near-uv CD spectroscopy. Interestingly, a significant change of the CD spectrum of $\beta$-LG was noticed upon addition of a stoichiometric amount of 7bd' and 7cd' as an increase of the CD signal was observed around $260 \mathrm{~nm}$ where the complexes absorb as well as a decrease of the intensity of the two bands at 285 and $293 \mathrm{~nm}$ assigned to the two Trp residues of $\beta$-LG (Fig. 4).

Figure 4. Near uv-CD spectra of $\beta$-LG (dotted black line) and stoichiometric mixtures of $\beta$-LG and Pd complexes 7ad', 7bd' and 7cd' in $20 \mathrm{mM}$ phosphate buffer $\mathrm{pH}$ 7.5.

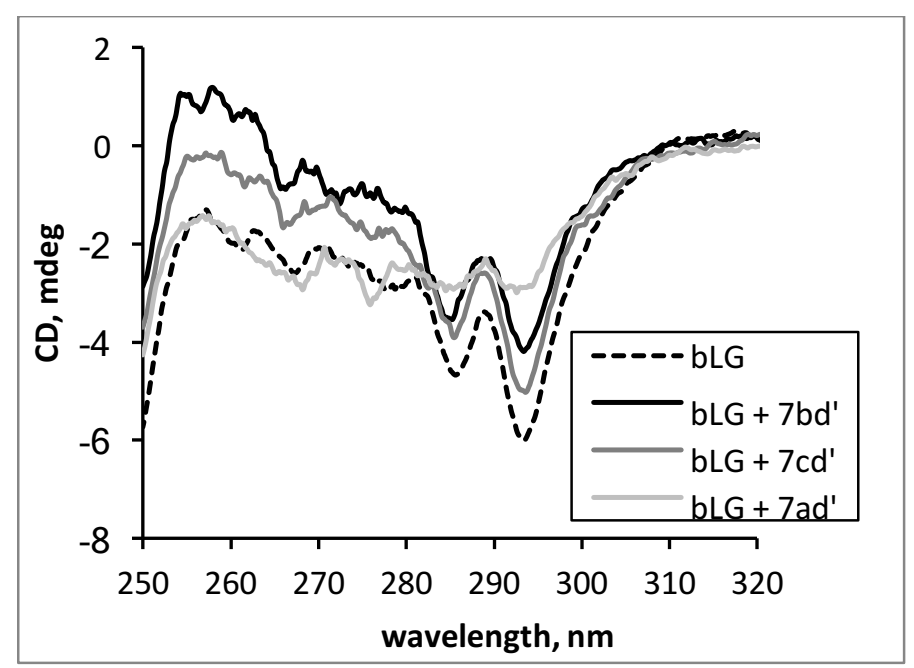

This induced positive CD signal is likely to be due to the binding of both complexes to $\beta$ LG and the positioning of the chromophore within the chiral environment of the protein. In contrast, addition of 7ad' to the solution of $\beta$-LG led to the nearly complete disappearance of the 2 negative bands at 285 and $293 \mathrm{~nm}$, indicating that the anisotropic environment of the tryptophan residues was disrupted by the presence of 
7ad'.[31] Since the far-uv CD spectrum of the mixture of $\beta$-LG and 7ad' was superimposable to that of $\beta$-LG alone (Fig. S1b), binding of 7ad' did not affect the secondary $\beta$-sheet structure of $\beta$-LG

\section{Catalysis studies}

Palladium pincer complexes display versatile catalytic properties. ${ }^{[19]}$ In particular, owing to their Lewis acid character originating from the labile chlorido ligand, these complexes have been successfully used in aldol and Michael type reactions. Both these reactions are synthetically very useful since they involve $\mathrm{C}-\mathrm{C}$ bond formation and creation of chiral centers. Aldol condensation between aldehydes and isocyanoacetates give access to oxazolines carrying 2 stereocenters (Scheme 6) which in turn afford $\beta$ hydroxyaminoacids upon hydrolysis. NCN pincer palladium complexes carrying C- and $\mathrm{N}$-centered stereogenic centers have been shown to catalyze such a reaction with variable regio- and enantioselectivities. ${ }^{[32]}$

Scheme 6. Aldol condensation between isocyanoacetate and aldehyde in aqueous medium

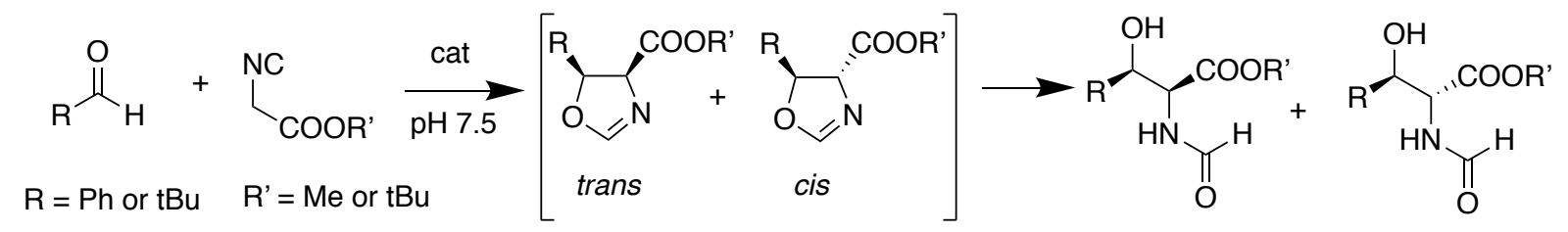

The first experiments were carried out with the benchmark substrates methyl isocyanoacetate and benzaldehyde ( $\mathrm{R}=\mathrm{Ph}, \mathrm{R}^{\prime}=\mathrm{Me}$ in Scheme 6). To the best of our knowledge, this reaction had never been attempted in aqueous medium. Therefore, the two substrates were allowed to react in phosphate buffer $\mathrm{pH} 7.5$ in the presence of a catalytic amount of $\mathrm{Pd}(\mathrm{OAc})_{2}$ at the preparative scale. In these conditions, no oxazoline was formed and the reaction product was identified as a formamide derivative (Scheme 6) resulting from opening of the oxazoline ring in the presence of water. ${ }^{1} \mathrm{H}$ NMR analysis of the raw product indicated that it was obtained as a mixture of cis- and transdiastereomers in the proportion 18/82 and a yield of 52 \% (Table 2). Purification by column chromatography yielded only the trans-diastereoisomer in a pure form. 
Prior to catalysis runs, the pincer complexes were treated with 1 eq. $\mathrm{AgBF}_{4}$ to generate the cationic complexes and silver salts were carefully removed from the reaction mixture by filtration on celite. In the ${ }^{1} \mathrm{H}$ NMR, formation of the cationic, aqua complex of $\mathbf{7 b a}$ ' resulted in the upfield shift of the protons of the 4 Me groups by $0.13 \mathrm{ppm}$ in agreement with literature data. ${ }^{[3]}$ In the ${ }^{13} \mathrm{C}$ NMR, the $\mathrm{C}$ coordinating the palladium center also underwent an upfield shift of ca. 5 ppm upon aquation. A cationic product with the same ${ }^{1} \mathrm{H}$ NMR spectrum was also obtained by treatment of $\mathbf{7} \mathbf{b a}$ ' with $\mathrm{Me}_{3} \mathrm{SiOTf}_{.}{ }^{[32 \mathrm{c}]}$ Then the reaction was performed at the analytical scale (2.5 $\left.\mu \mathrm{mol}\right)$ in the presence of $\beta$-lactoglobulin and $\mathbf{7} \mathbf{b b}^{\prime}$ or $\mathbf{7} \mathbf{b d d}^{\prime}$. As control experiments, the same reaction was carried out with the complexes alone, with the protein alone or without any additive. Disappearance of benzaldehyde was monitored by RP-HPLC analysis of the reaction mixtures each 15 min (Fig. S2). Rapid consumption of benzaldehyde was

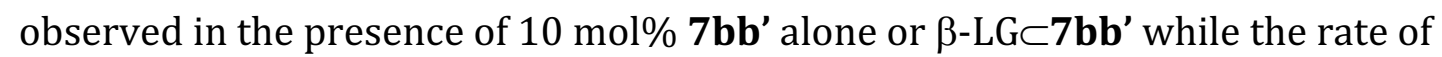

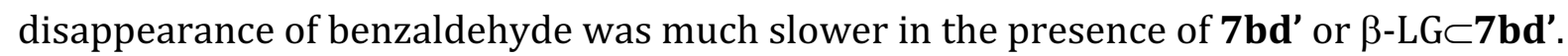
No difference of rate was noticed with or without $\beta$-LG. Noticeably, disappearance of benzaldehyde was even slower in the absence of Pd catalyst. Formation of formamide was checked by MS analysis. After $3 \mathrm{~h} 30$, conversions in formamide and diastereomeric ratios (d.r.) were calculated from the RP-HPLC profiles of the reaction mixtures. They were then extracted with diisopropyl ether and the organic extracts were analyzed by chiral HPLC to determine the enantiomeric ratios (e.r.) (Table 2).

Table 2. Aldol condensation of methyl isocyanoacetate and benzaldehyde ${ }^{a}$

\begin{tabular}{|c|c|c|c|c|}
\hline$\beta$-LG (mol\%) & Complex & Conversion $(\%)^{\mathrm{b}}$ & Trans/cis & e.r. $(\text { trans })^{\mathrm{c}}$ \\
\hline 0 & $\mathrm{Pd}(\mathrm{OAc})_{2}$ & 52 & $82 / 18$ & $50 / 50$ \\
\hline 0 & - & 3 & $50 / 50$ & $50 / 50$ \\
\hline 15 & - & 2 & $50 / 50$ & $50 / 50$ \\
\hline 0 & $7 \mathbf{b b}^{\prime}$ & 56 & $46 / 54$ & $50 / 50$ \\
\hline 15 & $7 \mathbf{b b}^{\prime}$ & 49 & $38 / 62$ & $50 / 50$ \\
\hline 0 & 7bd' & 7 & $49 / 51$ & $50 / 50$ \\
\hline 15 & 7bd' & 5 & $62 / 38$ & $57 / 43$ \\
\hline
\end{tabular}

a Reaction conditions: $2.5 \mu \mathrm{mol}$ methyl isocyanoacetate, $3 \mu \mathrm{mol}$ benzaldehyde, $10 \mathrm{~mol} \%$ complex in $0.5 \mathrm{ml} 20 \mathrm{mM}$ phosphate buffer $\mathrm{pH} 7.5,25^{\circ} \mathrm{C}, 3 \mathrm{~h} 30$

$\mathrm{b}$ determined by RP-HPLC analysis of the reaction mixtures on Nucleosil C18 HTec, $\mathrm{H}_{2} \mathrm{O} / \mathrm{MeCN} 95 / 5$ to $0 / 100$ in $40 \mathrm{~min}$ 
c determined by HPLC on Kromasil 5-cellucoat, hexane/isopropanol 98/2 for 19 min then to $96 / 4$ in $11 \mathrm{~min}$ at $1 \mathrm{ml} / \mathrm{min}$

In the absence of Pd catalyst (with or without $\beta-\mathrm{LG}$ ), conversions to formamide were very modest and product was obtained as a 1:1 mixture of cis and trans adducts. Both pincer complexes displayed some catalytic activity but $\mathbf{7} \mathbf{b} \mathbf{b}^{\prime}$ was much more active than 7bd'. This lack of activity of $\mathbf{7} \mathbf{b d}$ ' might be attributed to the presence of coordinating $\mathrm{OH}$ groups in $\beta$-position of the $\mathrm{N}$ atoms ${ }^{[32 \mathrm{~g}, \mathrm{~h}]}$ which compete with methyl isocyanoacetate for binding to the free coordination site on the metal center. In both cases, no regioselectivity was observed since the product was obtained as 1/1 trans/cis ratio. Finally, when the reaction was carried out in the presence of $\beta$-LG, slightly lower conversions were observed (compared to the complexes alone) as well as moderate

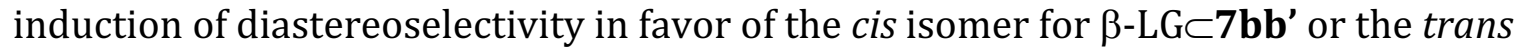

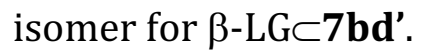

Another series of experiments was performed with more bulky substrates namely, pivalaldehyde and tert-butyl isocyanoacetate $\left(R=R^{\prime}=t B u\right.$ in Scheme 6). Results are gathered in Table 3. This time, no reaction occurred in the absence of catalyst, owing likely to the steric hindrance brought by the tert-butyl substituents borne by the 2 substrates.

Addition of $10 \mathrm{~mol} \% \mathrm{Pd}(\mathrm{OAc})_{2}$ to the mixture of substrates afforded exclusively the trans-formamide adduct in $60 \%$ conversion (Table 3). All the pincer palladium complexes also catalyzed the condensation of pivalaldehyde and tert-butyl isocyanoacetate to the corresponding formamide (as checked by MS), albeit with lower conversions compared to the former couple of substrates. Again, the 3 pincer palladium complexes with pendant $\mathrm{OH}$ groups (7ad' - 7cd') gave much lower yields than the 3 other complexes under study. In nearly all cases, only the trans-formamide adduct was obtained in agreement with the general trend observed with achiral and chiral pincer complexes ( $\mathrm{see}^{[32 \mathrm{~g}]}$ and refs. therein). Upon addition of $\beta$-LG, the diastereomeric ratio markedly changed since a significant proportion of cis-product was obtained. The cis-

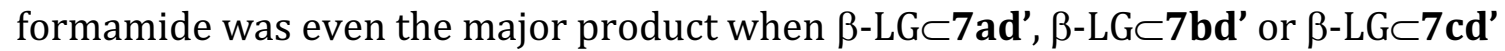
were used as catalysts.

Table 3. Aldol condensation of tert-butyl isocyanoacetate and pivalaldehyde ${ }^{a}$ 


\begin{tabular}{|l|l|l|l|}
\hline$\beta-L G(m o l \%)$ & Complex & Conversion (\%) $^{\mathrm{b}}$ & Trans/cis $^{\text {b }}$ \\
\hline 0 & 0 & 0 & - \\
\hline 0 & Pd(OAc) 2 & 60 & $100 / 0$ \\
\hline 10 & - & 0 & - \\
\hline 0 & 7ba' $^{\prime}$ & 44 & $100 / 0$ \\
\hline 10 & 7ba' $^{\prime}$ & 9 & $85 / 15$ \\
\hline 10 & 7ba'c $^{\prime}$ & 10 & $83 / 17$ \\
\hline 0 & 7bb' $^{\prime}$ & 28 & $100 / 0$ \\
\hline 10 & 7bb' $^{\prime}$ & 20 & $71 / 29$ \\
\hline 0 & 7bc' $^{\prime}$ & 16 & $50 / 50$ \\
\hline 10 & 7bc' $^{\prime}$ & 20 & $54 / 46$ \\
\hline 0 & 7bd' $^{\prime}$ & 5 & $100 / 0$ \\
\hline 10 & 7bd' $^{\prime}$ & 13 & $11 / 89$ \\
\hline 0 & 7ad' $^{\prime}$ & 11 & $100 / 0$ \\
\hline 10 & 7ad' $^{\prime}$ & 17 & $39 / 61$ \\
\hline 0 & 7cd' $^{\prime}$ & 5 & $100 / 0$ \\
\hline 10 & 7cd' $^{\prime}$ & 7 & $0 / 100$ \\
\hline
\end{tabular}

${ }^{a}$ Reaction conditions: $40 \mu \mathrm{mol}$ tert-butyl isocyanoacetate, $50 \mu \mathrm{mol}$ pivalaldehyde, 10 mol\% complex in $10 \mathrm{ml} 20 \mathrm{mM}$ phosphate buffer $\mathrm{pH} 7.5,3$ days at RT

${ }^{b}$ determined by HPLC on Kromasil 5-cellucoat, hexane/isopropanol 98/2 for 19 min then to $96 / 4$ in $11 \mathrm{~min}$ at $1 \mathrm{ml} / \mathrm{min}$

c 7ba' was treated with $\mathrm{Me}_{3} \mathrm{SiOTf}$ instead of $\mathrm{AgBF}_{4}$ before catalysis run

This series of assemblies gave slightly higher yields than the complexes alone and the proportion of cis-product increased with the aliphatic chain length. Such a change of d.r. may have been induced by the protein environment forming the second coordination sphere that favors the attack of the aldehyde on one side of the metal-bound enolate embedded in the protein. This may be the case for the hybrid catalysts resulting from the insertion of $\mathbf{7} \mathbf{b a}^{\prime}$ and $\mathbf{7} \mathbf{b} \mathbf{b}^{\prime}$ into $\beta$-LG and for which the same d.r. was determined. Alternatively, the metal complex may be forced by the protein host to adopt a preferential stereoconfiguration and diastereoselectivity subsequently transferred to the reaction product. This may be the case for the hybrids of 7ad', 7bd' and 7cd' that afforded from 61 to $100 \%$ of cis-product depending on the alkyl chain length. In the series of palladium catalysts, compound $\mathbf{7} \mathbf{b} \mathbf{c}^{\prime}$ behave anomalously since it afforded an equimolar mixture of cis- and trans-isomers and addition of $\beta$-LG had no influence on 
the reaction outcome, which infers that this complex is unable to bind to the protein host.

\section{Conclusions}

To sum up, we synthesized and characterized several new prochiral pincer palladium(II) complexes based on hemilabile ligands and studied their structural properties. ${ }^{1} \mathrm{H}$ NMR studies showed that, in solution, complexes $\mathbf{7} \mathbf{b b}^{\prime}$ and $\mathbf{7} \mathbf{b} \mathbf{c}^{\prime}$ carrying stereogenic centers on the $\mathrm{N}$-donor atoms exist as mixtures of diastereoisomers with diastereomeric ratios of 61:39 and 56:44, respectively. Moreover, it was found that the cis/trans exchange occurs and it could be accelerated in coordinating solvents and by heating. Circular dichroism experiments suggested that insertion of some of the pincer complexes into $\beta$ lactoglobulin cavity did occur. This assumption was nicely confirmed by molecular docking simulations. Unfortunately, no evidence of the influence of protein's tertiary structure on the stereoconfiguration of complex $\mathbf{7} \mathbf{b} \mathbf{b}^{\prime}$ was revealed by experimental circular dichroism spectroscopy, probably because of the poor chromophoric properties of this compound. Adjunction of H-bond donor substituents on the ligand framework gave much more stable supramolecular assemblies as suggested by molecular docking simulations and then confirmed by experimental CD measurements. All the hybrid constructs were shown to catalyze aldol condensation reactions between isocyanoacetates and aldehydes to afford $\beta$-hydroxyaminoacid precursors. Unusual regioselectivity toward the cis-product was found by combining $\beta$-LG and the pincer complexes carrying $\mathrm{OH}$ substituents, which may validate the "dormant chirality" concept.

\section{Experimental section}

\section{Materials}

All reactions were performed in oven-dried glassware and under inert atmosphere. All starting materials, reagents, and catalysts were obtained from commercial suppliers and used without further purification. Diethyl-5-aminoisophthalate 2,[20a] (5-amino-1,3phenylene)dimethanol $\mathbf{3}^{[20 \mathrm{~b}]}$ and $\mathrm{N}$-[3,5-bis(hydroxymethyl)phenyl]hexadecanamide $\mathbf{4} \mathbf{b}^{[34]}$ were synthesized following literature protocols. Bovine $\beta$-lactoglobulin ( $\beta$-LG; mixture of isoforms A and B) was purchased from Sigma (ref L2506). Anhydrous tetrahydrofuran (THF) was obtained by Pure Solv ${ }^{\mathrm{TM}}$ Purification System. Analytical thin 
layer chromatography was performed with Merck silica gel 60F glass plates and flash chromatography by use of Merck silica gel 60 (230-400 mesh). ${ }^{1} \mathrm{H}$ and ${ }^{13} \mathrm{C}$ NMR spectra were recorded on AV400 and AV250 NMR spectrometers (Bruker). Chemical shifts $(\delta)$ are expressed as ppm referenced to the solvent residual signals (i.e. chloroform, ${ }^{1} \mathrm{H} \delta$ $7.26 \mathrm{ppm},{ }^{13} \mathrm{C} \delta 77.2 \mathrm{ppm}$, dimethyl sulfoxide, ${ }^{1} \mathrm{H} \delta 2.50 \mathrm{ppm},{ }^{13} \mathrm{C} \delta 39.5 \mathrm{ppm}$ and methanol, $\left.{ }^{1} \mathrm{H} \delta 3.31 \mathrm{ppm},{ }^{13} \mathrm{C} \delta 49.0 \mathrm{ppm}\right)$. Splitting patterns are expressed as follows: $\mathrm{s}$, singlet; d, doublet; t, triplet; q, quartet; p, pentet; m, multiplet; br, broad. High-resolution mass spectra (HRMS) are reported in $m / z$.

\section{Methods}

N-(3,5-bis(hydroxymethyl)phenyl)dodecanamide (4a): Lauric acid (396 mg, 1.98 mmol), $N$-hydroxybenzotriazole (101 $\mathrm{mg}, 0.75 \mathrm{mmol}$ ) and (5-amino-1,3phenylene)dimethanol (2) (310 mg, $2 \mathrm{mmol}$ ) were dissolved in THF (20 mL). The resulting solution was cooled to $0^{\circ} \mathrm{C}$ and a solution of EDCI (378 mg, $1.98 \mathrm{mmol}$ ) in DMF ( $3 \mathrm{~mL}$ ) was added. The resulting mixture was refluxed for $24 \mathrm{~h}$. Then, water was added and the precipitate was filtered off and dried. Yield: $540 \mathrm{mg}(81 \%)$. Mp: $76{ }^{\circ} \mathrm{C} .{ }^{1} \mathrm{H}$ NMR (400 MHz, MeOD) $\delta 0.79(\mathrm{t}, J=6.9 \mathrm{~Hz}, 3 \mathrm{H}), 1.19(\mathrm{~m}, 16 \mathrm{H}), 1.59(\mathrm{~m}, 2 \mathrm{H}), 2.26(\mathrm{t}, J=7.5 \mathrm{~Hz}$, 2H), $4.48(\mathrm{~s}, 4 \mathrm{H}), 7.00$ (s, 1H), 7.37 (s, 2H). ${ }^{13} \mathrm{C}$ NMR (101 MHz, MeOD) $\delta$ 14.8, 24.1, 26.1, 27.3, 30.7, 30.8, 31.1, 33.4, 35.1, 38.4, 65.4, 119.1, 122.4, 140.4, 144.0, 175.1. IR (U, cm-1): 3257, 2920, 2850, 1653, 1541, 1456, 1438, 1062, 1011, 850. ESI-HRMS (m/z): found: $358.2361\left(\mathrm{M}+\mathrm{Na}^{+}\right.$) (calc for $\left.\mathrm{C}_{20} \mathrm{H}_{33} \mathrm{NNaO}_{3}: 358.2353\right)$.

N-(3,5-bis(hydroxymethyl)phenyl)stearamide (4c): Stearoyl chloride (453 mg, 1.5 mmol), sodium hydrogenocarbonate (378 mg, $4.5 \mathrm{mmol}$ ) and (5-amino-1,3phenylene)dimethanol (2) (232 mg, $1.5 \mathrm{mmol}$ ) were dissolved in THF (10 mL), the resulting solution was refluxed for $16 \mathrm{~h}$. Then, the reaction mixture was poured into water and the precipitate was filtered off and dried. Yield: $550 \mathrm{mg}(87 \%) . \mathrm{Mp}: 114^{\circ} \mathrm{C} .{ }^{1} \mathrm{H}$ NMR (400 MHz, DMSO- $\left.d^{6}\right) \delta 0.85(\mathrm{t}, J=7.5 \mathrm{~Hz}, 3 \mathrm{H}), 1.23(\mathrm{~m}, 28 \mathrm{H}), 1.57(\mathrm{~m}, 2 \mathrm{H}), 2.27(\mathrm{t}, J$ $=7.5 \mathrm{~Hz}, 2 \mathrm{H}), 4.44(\mathrm{~s}, 4 \mathrm{H}), 5.12(\mathrm{~s}, 2 \mathrm{H}), 6.43(\mathrm{~s}, 1 \mathrm{H}), 7.43(\mathrm{~s}, 2 \mathrm{H}), 9.76(\mathrm{~s}, 1 \mathrm{H}) .{ }^{13} \mathrm{C} \mathrm{NMR}$ $\left(101 \mathrm{MHz}, \mathrm{DMSO}-d^{6}\right) \delta 14.4,22.6,25.7,28.7,29.2,29.6,31.8,32.5,36.9,63.5,116.0$, 119.5, 139.5, 143.2, 171.5. IR (v, $\mathrm{cm}^{-1}$ ): 3334, 2910, 2850, 1722, 1661, 1546, 1468, 1439, 1410, 1301, 1188, 1085, 1028, 867. ESI-HRMS (m/z): found: $442.3279\left(\mathrm{M}+\mathrm{Na}^{+}\right)$(calc for $\mathrm{C}_{26} \mathrm{H}_{45} \mathrm{NO}_{3} \mathrm{Na}$ : 442.3292). 
N-(3,5-bis(bromomethyl)phenyl)dodecanamide (5a): General procedure A: N-(3,5bis(hydroxymethyl)phenyl)dodecanamide 4 a (580 mg, $1.72 \mathrm{mmol}$ ) was dissolved in 6 $\mathrm{mL}$ of $33 \%$ solution of $\mathrm{HBr}$ in glacial acetic acid and the resulting mixture was stirred overnight at room temperature. Then, the reaction mixture was poured into water (100 $\mathrm{mL}$ ), the precipitate was collected, washed with petroleum ether and dried. Yield: 371 mg (76 \%). Mp: $116^{\circ} \mathrm{C} .{ }^{1} \mathrm{H}$ NMR (400 MHz, CDCl $) \delta 0.89(\mathrm{t}, \mathrm{J}=7.0 \mathrm{~Hz}, 3 \mathrm{H}), 1.27(\mathrm{~m}$, 16H), $1.72(\mathrm{~m}, 2 \mathrm{H}), 2.36(\mathrm{t}, \mathrm{J}=7.4 \mathrm{~Hz}, 2 \mathrm{H}), 4.43(\mathrm{~s}, 4 \mathrm{H}), 7.16(\mathrm{~s}, 1 \mathrm{H}), 7.27(\mathrm{~s}, 1 \mathrm{H}), 7.54(\mathrm{~s}$, 2H). ${ }^{13} \mathrm{C}$ NMR (101 MHz, $\left.\mathrm{CDCl}_{3}\right) \delta 14.1,22.7,29.2,29.5,29.6,32.3,32.5,37.7,120.1$, 125.1, 138.7, 139.2, 171.5. IR (v, $\mathrm{cm}^{-1}$ ): 2918, 2850, 2360, 1658, 1612, 1557, 1466, 1437, 1245, 1208, 1159, 1102, 876, 721. ESI-HRMS (m/z): found: $484.0634\left(\mathrm{M}+\mathrm{Na}^{+}\right)$(calc for $\mathrm{C}_{20} \mathrm{H}_{31} \mathrm{Br}_{2} \mathrm{NNaO}$ : 484.0645).

N-(3,5-bis(bromomethyl)phenyl)stearamide (5c): Following procedure A from 4c (589 mg, $1.40 \mathrm{mmol}$ ). Yield: $690 \mathrm{mg}$ (90\%). Mp: $117^{\circ} \mathrm{C} .{ }^{1} \mathrm{H}$ NMR (400 MHz, $\left.\mathrm{CDCl}_{3}\right) \delta$ $0.89(\mathrm{t}, J=6.4 \mathrm{~Hz}, 3 \mathrm{H}), 1.26(\mathrm{~m}, 28 \mathrm{H}), 1.73(\mathrm{~m}, 2 \mathrm{H}), 2.36(\mathrm{t}, J=7 . \mathrm{Hz}, 2 \mathrm{H}), 4.44(\mathrm{~s}, 4 \mathrm{H})$, 7.16 (s, 1H), $7.24(\mathrm{~s}, 1 \mathrm{H}), 7.54(\mathrm{~s}, 2 \mathrm{H}) .{ }^{13} \mathrm{C}$ NMR (101 MHz, $\left.\mathrm{CDCl}_{3}\right) \delta 14.1,22.7,25.5,29.2$, 29.65, 29.69, 29.8, 31.6, 32.5, 37.8, 120.1, 125.1, 138.7, 139.2, 171.5. IR (v, $\left.\mathrm{cm}^{-1}\right): 2918$, 2850, 2360, 1660 1606, 1546, 1463, 1439, 1255, 1238, 1209, 1106, 878, 719. ESI-HRMS (m/z): found: $568.1573\left(\mathrm{M}+\mathrm{Na}^{+}\right.$) (calc for $\mathrm{C}_{26} \mathrm{H}_{43} \mathrm{Br}_{2} \mathrm{NNaO}: 568.1604$ ).

N-[3,5-bis(bromomethyl)phenyl]hexadecanamide (5b): Following procedure A from $4 \mathbf{b}$ (1.17 g, $3 \mathrm{mmol}$ ) and $10 \mathrm{~mL}$ of $33 \%$ solution of $\mathrm{HBr}$ in glacial acetic acid. Yield: $1.5 \mathrm{~g}$ (97\%). Mp: $120{ }^{\circ} \mathrm{C} .{ }^{1} \mathrm{H}$ NMR (400 MHz, $\left.\mathrm{CDCl}_{3}\right) \delta 0.89(\mathrm{t}, J=6.5 \mathrm{~Hz}, 3 \mathrm{H}), 1.27(\mathrm{~m}, 24 \mathrm{H})$, $1.73(\mathrm{~m}, 2 \mathrm{H}), 2.36(\mathrm{t}, J=7.4 \mathrm{~Hz}, 2 \mathrm{H}), 4.44(\mathrm{~s}, 4 \mathrm{H}), 7.16(\mathrm{~s}, 1 \mathrm{H}), 7.19(\mathrm{~s}, 1 \mathrm{H}), 7.54(\mathrm{~s}, 2 \mathrm{H})$. ${ }^{13} \mathrm{C}$ NMR $\left(101 \mathrm{MHz}, \mathrm{CDCl}_{3}\right) \delta 14.1,22.7,25.5,29.4,29.6,32.5,37.8,120.1,125.1,138.7$, 139.3, 171.5. IR (U, $\mathrm{cm}^{-1}$ ): 2918, 2850, 2360, 1658, 1612, 1558, 1466, 1438, 1265, 1208, 1159, 1102, 875, 721. ESI-HRMS (m/z): found: $540.1278\left(\mathrm{M}+\mathrm{Na}^{+}\right.$) (calc for $\mathrm{C}_{24} \mathrm{H}_{39} \mathrm{Br}_{2} \mathrm{NNaO}$ : 540.1272).

N-(3,5-bis((dimethylamino)methyl)phenyl)dodecanamide (6aa'): Procedure B: A $40 \%$ aqueous solution of dimethylamine ( $5 \mathrm{~mL}$ ) was added to a suspension of $\mathbf{5 a}$ (570 $\mathrm{mg}, 1.23 \mathrm{mmol}$ ) and potassium carbonate (803 mg, $5.82 \mathrm{mmol}$ ) in MeCN (20 mL). The resulting mixture was refluxed overnight, then cooled to room temperature and diluted with water $(20 \mathrm{~mL})$ and DCM $(25 \mathrm{~mL})$. The organic layer was separated and the aqueous phase was extracted with DCM $(2 \times 25 \mathrm{~mL})$. The organic phases were combined, dried over $\mathrm{Na}_{2} \mathrm{SO}_{4}$ and evaporated to dryness. The residue was purified by flash 
chromatography (DCM, then DCM/EtOH 97/3, then DCM/EtOH/NEt 3 93/5/2). Yield: $560 \mathrm{mg}$ (99\%). Mp: $57^{\circ} \mathrm{C} .{ }^{1} \mathrm{H}$ NMR (400 MHz, MeOD) $\delta 0.73(\mathrm{t}, J=7.0 \mathrm{~Hz}, 3 \mathrm{H}), 1.10(\mathrm{~m}$, $16 \mathrm{H}), 1.54(\mathrm{q}, J=7.5 \mathrm{~Hz}, 2 \mathrm{H}), 2.05(\mathrm{~s}, 12 \mathrm{H}), 2.18(\mathrm{t}, J=7.5 \mathrm{~Hz}, 2 \mathrm{H}), 3.20(\mathrm{~s}, 4 \mathrm{H}), 6.85(\mathrm{~s}$, 1H), 7.27 (s, 2H), 7.99 (s, 1H). ${ }^{13}$ C NMR (101 MHz, MeOD) $\delta 13.9,22.4,25.5,29.1,29.4$, 31.6, 37.4, 45.1, 63.8, 119.2, 125.1, 137.9, 139.3, 171.6. IR (u, cm-1): 2918, 2850, 1660, 1610, 1541, 1470, 1355, 1174, 1097, 877, 716. ESI-HRMS (m/z): found: 390.3482 $\left(\mathrm{M}+\mathrm{H}^{+}\right.$) (calc for $\mathrm{C}_{24} \mathrm{H}_{44} \mathrm{~N}_{3} \mathrm{O}: 390.3479$ ).

N-(3,5-bis((dimethylamino)methyl)phenyl)stearamide (6ca'): Following procedure B: from a $40 \%$ aqueous solution of dimethylamine ( $3 \mathrm{~mL}$ ), $\mathbf{5 c}$ (200 $\mathrm{mg}, 0.37 \mathrm{mmol})$ and potassium carbonate (306 mg, $2.22 \mathrm{mmol}$ ) in MeCN (15 mL). Yield: $280 \mathrm{mg}$ (99\%). Mp: $63{ }^{\circ} \mathrm{C} .{ }^{1} \mathrm{H}$ NMR (400 MHz, MeOD) $\delta 0.88(\mathrm{t}, J=6.7 \mathrm{~Hz}, 3 \mathrm{H}), 1.25(\mathrm{~m}, 28 \mathrm{H}), 1.70(\mathrm{~m}, 2 \mathrm{H})$, 2.26 (s, 12H), 2.33 (t, J = 7.5 Hz, 2H), 3.42 (s, 4H), $7.02(\mathrm{~s}, 1 \mathrm{H}), 7.35$ (s, 1H), $7.43(\mathrm{~s}, 2 \mathrm{H})$. ${ }^{13} \mathrm{C}$ NMR (101 MHz, MeOD) $\delta$ 14.2, 22.7, 25.6, 29.3, 29.4, 29.7, 31.9, 45.3, 64.0, 119.3, 125.6, 138.1, 139.4, 171.4. IR (v, $\mathrm{cm}^{-1}$ ): 2918, 2850, 1660, 1610, 1541, 1470, 1353, 1175, 1095, 874, 716. ESI-HRMS (m/z): found: $474.4491\left(\mathrm{M}+\mathrm{H}^{+}\right.$) (calc for $\mathrm{C}_{30} \mathrm{H}_{56} \mathrm{~N}_{3} \mathrm{O}$ : 474.4421).

N-\{3,5-bis[(dimethylamino)methyl]phenyl\}hexadecanamide (6ba'): Following procedure B from a $40 \%$ aqueous solution of dimethylamine $(5 \mathrm{~mL}), \mathbf{5 b}(517 \mathrm{mg}, 1$ mmol) and potassium carbonate (828 mg, $6 \mathrm{mmol})$ in MeCN (20 mL). Yield: $317 \mathrm{mg}$ (71\%). Mp: $60{ }^{\circ} \mathrm{C} .{ }^{1} \mathrm{H}$ NMR (400 MHz, $\left.\mathrm{CDCl}_{3}\right) \delta 0.88(\mathrm{t}, J=6.8 \mathrm{~Hz}, 3 \mathrm{H}), 1.26(\mathrm{~m}, 24 \mathrm{H}), 1.71$ $(\mathrm{m}, 2 \mathrm{H}), 2.25(\mathrm{~s}, 12 \mathrm{H}), 2.32(\mathrm{t}, J=7.5 \mathrm{~Hz}, 2 \mathrm{H}), 3.41(\mathrm{~s}, 4 \mathrm{H}), 7.02(\mathrm{~s}, 1 \mathrm{H}), 7.23$ (br. s, 1H), 7.41 (s, 2H). ${ }^{13} \mathrm{C}$ NMR (101 MHz, CDCl $) \delta 14.1,22.7,25.6,29.37,29.45,29.7,31.9,37.8$, $45.3,64.0,119.2,125.5,138.0,139.6,171.3$. IR $\left(\mathrm{v}, \mathrm{cm}^{-1}\right): 2918,2850,1660,1610,1541$, 1470, 1456, 1415, 1173, 1097, 877, 716. ESI-HRMS (m/z): found: $446.4104\left(\mathrm{M}+\mathrm{H}^{+}\right)$ (calc. for $\mathrm{C}_{28} \mathrm{H}_{52} \mathrm{~N}_{3} \mathrm{O}: 446.4105$ ).

N-(3,5-bis $\{[$ ethyl(methyl)amino]methyl\}phenyl)hexadecanamide (6bb'): Following procedure B from $\mathbf{5 b}$ (400 mg, $0.77 \mathrm{mmol}$ ), $\mathrm{K}_{2} \mathrm{CO}_{3}(638 \mathrm{mg}, 4.62 \mathrm{mmol}$ ) and $N$ ethylmethylamine (137 mg, $0.2 \mathrm{~mL}, 2.32 \mathrm{mmol}$ ). Yield: $201 \mathrm{mg}(55 \%)$. Mp: $39{ }^{\circ} \mathrm{C} .{ }^{1} \mathrm{H}$ NMR (400 MHz, $\left.\mathrm{CDCl}_{3}\right) \delta 0.88(\mathrm{t}, J=6.9 \mathrm{~Hz}, 3 \mathrm{H}), 1.12(\mathrm{t}, J=7.2 \mathrm{~Hz}, 6 \mathrm{H}), 1.26(\mathrm{~m}, 24 \mathrm{H})$, $1.71(\mathrm{~m}, 2 \mathrm{H}), 2.22(\mathrm{~s}, 6 \mathrm{H}), 2.33(\mathrm{t}, J=7.5 \mathrm{~Hz}, 2 \mathrm{H}), 2.49(\mathrm{q}, J=7.2 \mathrm{~Hz}, 4 \mathrm{H}), 3.51(\mathrm{~s}, 4 \mathrm{H})$, 7.06 (s, 1H), 7.46 (s, 2H). ${ }^{13} \mathrm{C}$ NMR (101 MHz, $\left.\mathrm{CDCl}_{3}\right) \delta 12.1,14.1,22.7,25.6,29.3,29.5$, 29.6, 31.9, 37.8, 41.4, 51.2, 61.5, 119.3, 125.7, 138.1, 139.3, 171.4. IR (v, $\mathrm{cm}^{-1}$ ): 2917, 
2850, 1660, 1609, 1542, 1470, 1170, 1098, 1046, 871, 716. ESI-HRMS (m/z): found: 474.4406 $\left(\mathrm{M}+\mathrm{H}^{+}\right.$) (calc. for $\mathrm{C}_{30} \mathrm{H}_{56} \mathrm{~N}_{3} \mathrm{O}: 474.4418$ ).

$\boldsymbol{N}$-(3,5-bis $\{[$ benzyl(ethyl)amino]methyl\}phenyl)hexadecanamide (6bc'): Following procedure B from $\mathbf{5 b}(207 \mathrm{mg}, 0.4 \mathrm{mmol}), \mathrm{K}_{2} \mathrm{CO}_{3}(332 \mathrm{mg}, 2.4 \mathrm{mmol})$ and $\mathrm{N}$ ethylbenzylamine $(113 \mathrm{mg}, 125 \mu \mathrm{L}, 0.84 \mathrm{mmol})$. The product was purified by flash chromatography (PE/AcOEt 8/2, then 1/1). Yield: $193 \mathrm{mg}$ (77\%). Mp: $36{ }^{\circ} \mathrm{C} .{ }^{1} \mathrm{H}$ NMR $\left(400 \mathrm{MHz}, \mathrm{CDCl}_{3}\right) \delta 0.78(\mathrm{t}, J=6.8 \mathrm{~Hz}, 3 \mathrm{H}), 0.97(\mathrm{t}, J=7.1 \mathrm{~Hz}, 6 \mathrm{H}), 1.17(\mathrm{~m} \mathrm{24H}), 1.63(\mathrm{~m}$, 2H), $2.24(\mathrm{t}, J=7.5 \mathrm{~Hz}, 2 \mathrm{H}), 2.41(\mathrm{q}, J=7.1 \mathrm{~Hz}, 4 \mathrm{H}), 3.45(\mathrm{~s}, 4 \mathrm{H}), 3.48$ (s, 4H), 7.10 (br s, 1H), $7.14(\mathrm{~m}, 3 \mathrm{H}), 7.19(\mathrm{~m}, 4 \mathrm{H}), 7.28(\mathrm{~m}, 4 \mathrm{H}), 7.33$ (br s, 1H). ${ }^{13} \mathrm{C}$ NMR (101 MHz, $\left.\mathrm{CDCl}_{3}\right)$ $\delta 12.0,14.1,22.7,25.6,29.28,29.33,29.7,31.9,37.9,47.1,57.6,57.7,118.5,125.0,126.7$, 128.1, 128.8, 137.9, 139.8, 140.7, 171.3. IR (v, cm-1): 2918, 2849, 1657, 1613, 1558, 1461, 1382, 1251, 1149, 1073, 867, 735. ESI-HRMS (m/z): found: $626.5022\left(\mathrm{M}+\mathrm{H}^{+}\right)$ (calc. for $\mathrm{C}_{42} \mathrm{H}_{64} \mathrm{~N}_{3} \mathrm{O}: 626.5044$ ).

\section{N-(3,5-bis \{[ethanol(methyl)amino]methyl\}phenyl)dodecanamide (6ad'):}

Procedure C: N-[3,5-bis(bromomethyl)phenyl]dodecanamide 5a (200 mg, $0.43 \mathrm{mmol}$ ) was dissolved in acetonitrile $(20 \mathrm{~mL})$, then $\mathrm{K}_{2} \mathrm{CO}_{3}(237 \mathrm{mg}, 1.72 \mathrm{mmol})$ and methylaminoethanol $(0.4 \mathrm{~mL}, 0.86 \mathrm{mmol})$ were added. The mixture was stirred overnight at reflux. After acetonitrile was evaporated under reduced pressure, DCM was added (30 mL), and the solution was washed with water, $\mathrm{NaHCO}_{3}$ solution, dried over anhydrous $\mathrm{Na}_{2} \mathrm{SO}_{4}$ and evaporated under reduced pressure to afford 6ad' as a brown solid. Yield: $200 \mathrm{mg}$ (99\%). Mp: $\left.45^{\circ} \mathrm{C}^{1} \mathrm{H} \mathrm{NMR} \mathrm{(400} \mathrm{MHz,} \mathrm{CDCl} 3\right) \delta 0.82$ (t, J=6.6 Hz, $3 \mathrm{H}$ ), $1.19(\mathrm{~m}, 18 \mathrm{H}), 1.63(\mathrm{~m}, 2 \mathrm{H}), 2.16(\mathrm{~s}, 6 \mathrm{H}), 2.26(\mathrm{t}, J=7.5 \mathrm{~Hz}, 2 \mathrm{H}), 2.47(\mathrm{t}, J=5.2 \mathrm{~Hz}, 4 \mathrm{H})$, 3.42 (s, 4 H), 3.54 (t, J = 5.3 Hz, 4 H), 3.62 (br. s., 3 H), 6.91 (s, 1 H), 7.38 (s, 2 H), 8.35 (br. S., $1 \mathrm{H}) .{ }^{13} \mathrm{C}$ NMR $\left(101 \mathrm{MHz}, \mathrm{CDCl}_{3}\right) \delta 13.9,22.4,25.4,29.1,29.14,29.2,29.3,29.38,29.42$, 31.6, 37.3, 41.7, 53.3, 58.2, 58.4, 62.0, 119.1, 124.8, 138.3, 139.1, 171.9. IR (u, $\left.\mathrm{cm}^{-1}\right)$ : 3291, 2918, 2849, 1660, 1610, 1544, 1464, 1123, 1077, 1028, 877, 720. ESI-HRMS (m/z): found: $450.3685(\mathrm{M}+\mathrm{H})$ (calc. for $\left.\mathrm{C}_{26} \mathrm{H}_{48} \mathrm{~N}_{3} \mathrm{O}_{3}: 450.3690\right)$.

N-(3,5-bis $\{[$ ethanol(methyl)amino]methyl\}phenyl)stearamide (6cd'): Following procedure C from 5c (200 mg, $0.37 \mathrm{mmol}), \mathrm{K}_{2} \mathrm{CO}_{3}(204 \mathrm{mg}, 1.48 \mathrm{mmol}$ ) and methylaminoethanol (0.2 mL, $0.74 \mathrm{mmol})$. Yield: $157 \mathrm{mg}$ (78\%). Mp: $65^{\circ} \mathrm{C} .{ }^{1} \mathrm{H} \mathrm{NMR}$

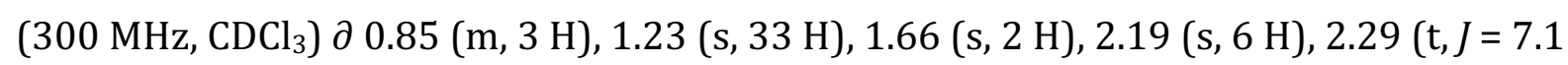
Hz, 3 H), 2.51 (s, 4 H), 3.36 (s, 2 H), 3.46 (s, 4 H), 3.57 (s, 4 H), 6.95 (s, 1 H), 7.39 (s, 2 H), 8.06 (s, $1 \mathrm{H}) .{ }^{13} \mathrm{C}$ NMR $\left(101 \mathrm{MHz}, \mathrm{CDCl}_{3}\right)$ d 13.9, 22.5, 25.4, 29.1, 29.2, 29.3, 29.4, 29.5, 
29.5, 31.7, 37.3, 41.7, 58.3, 58.4, 61.9, 119.3, 124.9, 138.5, 138.7, 172.0. IR (u, $\left.\mathrm{cm}^{-1}\right)$ : 3292, 2918, 2849, 1659, 1611, 1545, 1465, 1169, 1075, 1015, 875, 681. ESI-HRMS (m/z): found: $534.4650(\mathrm{M}+\mathrm{H})$ (calc. for $\mathrm{C}_{32} \mathrm{H}_{60} \mathrm{~N}_{3} \mathrm{O}_{3}$ : 534.4629).

\section{N-(3,5-bis\{[ethanol(methyl)amino]methyl\}phenyl)hexadecanamide (6bd'):}

Following Procedure C from $5 \mathbf{b}$ (200 mg, $0.38 \mathrm{mmol}), \mathrm{K}_{2} \mathrm{CO}_{3}(210 \mathrm{mg}, 1.52 \mathrm{mmol})$ and methylaminoethanol (0.3 mL, $0.80 \mathrm{mmol})$. Yield: $167 \mathrm{mg}(87 \%)$. Mp: $57{ }^{\circ} \mathrm{C} .{ }^{1} \mathrm{H}$ NMR $\left(400 \mathrm{MHz}, \mathrm{CDCl}_{3}\right) \partial 0.86(\mathrm{t}, J=6.8 \mathrm{~Hz}, 4 \mathrm{H}), 1.24(\mathrm{~s}, 30 \mathrm{H}), 1.68(\mathrm{~m}, 2 \mathrm{H}), 2.24(\mathrm{~s}, 6 \mathrm{H})$, $2.34(\mathrm{~m}, 2 \mathrm{H}), 2.56(\mathrm{~m}, 4 \mathrm{H}), 3.52(\mathrm{~s}, 4 \mathrm{H}), 3.61(\mathrm{t}, J=4.73 \mathrm{~Hz}, 4 \mathrm{H}), 3.81(\mathrm{~m}, 2 \mathrm{H}), 6.99(\mathrm{~s}, 1$ H), 7.45 (s, 2 H), 8.00 (s, 1 H). ${ }^{13}$ C NMR (101 MHz, $\left.\mathrm{CDCl}_{3}\right)$ d 14.0, 22.6, 25.5, 29.3, 29.5, 29.6, 31.8, 37.5, 41.8, 41.8, 58.3, 61.9, 76.6, 77.4, 119.6, 125.3, 138.7, 172.1. IR (u, $\left.\mathrm{cm}^{-1}\right)$ : 3284, 2918, 2849, 1660, 1611, 1547, 1464, 1187, 1079, 1027, 875, 720. ESI-HRMS (m/z): found: $506.4311(\mathrm{M}+\mathrm{H})$ (calc. for $\mathrm{C}_{30} \mathrm{H}_{55} \mathrm{~N}_{3} \mathrm{O}_{3}$ : 506.4316).

Palladium(II) pincer complex 7aa': Procedure D: Mercury(II) acetate (67.0 mg, 0.21 mmol) was added to a solution of 6aa' (100 mg, $0.21 \mathrm{mmol})$ in absolute ethanol $(10 \mathrm{~mL})$ and the resulting mixture was refluxed for $24 \mathrm{~h}$. Then, excess $\mathrm{LiCl}$ was added to the reaction mixture and refluxed for $15 \mathrm{~min}$. Then, the solvent was evaporated and the residue partitioned in DCM/water $(20 \mathrm{~mL} / 10 \mathrm{~mL})$. The organic phase was separated and the aqueous phase was extracted with DCM $(2 \times 20 \mathrm{~mL})$. Organic extracts were combined, dried over $\mathrm{Na}_{2} \mathrm{SO}_{4}$ and evaporated. The product was used in the next step without further purification. Yield: $70 \mathrm{mg}(57 \%)$. The mercurated derivative $(70 \mathrm{mg}$, $0.11 \mathrm{mmol}$ ) was dissolved in DCM/MeOH (2:1, $15 \mathrm{~mL})$ and $\mathrm{Pd}(\mathrm{OAc})_{2}(18.4 \mathrm{mg}, 0.11$ mmol) was added to this solution. The resulting mixture was stirred overnight at room temperature. Then, the solution was filtered on Celite and the filtrate evaporated. The residue was redissolved in $\mathrm{MeOH}(10 \mathrm{~mL})$ and treated with $\mathrm{LiCl}$ for $1 \mathrm{~h}$. The solvent was removed under vacuum and the residue redissolved in DCM (15 $\mathrm{mL})$ and this solution was filtered through Celite. The filtrate was evaporated and the residue was purified by flash chromatography (DCM/EtOH 24/1). Yield: $41 \mathrm{mg}$ (77 \%). ${ }^{1} \mathrm{H}$ NMR (400 MHz, MeOD) $\delta 0.89(\mathrm{t}, \mathrm{J}=6.7 \mathrm{~Hz}, 3 \mathrm{H}), 1.28(\mathrm{~s}, 16 \mathrm{H}), 1.66(\mathrm{~m}, 2 \mathrm{H}), 2.35(\mathrm{dt}, J=14.3,7.0 \mathrm{~Hz}, 2 \mathrm{H})$,

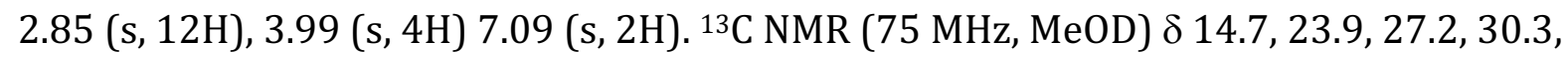
30.5, 30.6, 30.6, 30.8, 30.9, 33.2, 38.2, 53.5, 75.6, 113.9, 137.2, 146.7, 152.0, 174.4. IR (v, $\mathrm{cm}^{-1}$ ): 2918, 2849, 1654, 1599, 1542, 1452, 1337, 1258, 1180, 1042, 1028, 868, 720. ESIHRMS (m/z): found: $494.0236\left(\mathrm{M}-\mathrm{Cl}^{-}\right.$) (calc for $\mathrm{C}_{24} \mathrm{H}_{43} \mathrm{~N}_{3} \mathrm{OPd}$ : 494.1247). 
7ca': Following procedure D with $\mathrm{Hg}(\mathrm{OAc})_{2}(67.0 \mathrm{mg}, 0.21 \mathrm{mmol})$ and 6ca' (100 mg, $0.21 \mathrm{mmol})$. Yield: $80 \mathrm{mg}$ (57 \%); then Pd(OAc) 2 (18.2 $\mathrm{mg}, 0.11 \mathrm{mmol})$ to afford 7ca'. Yield: $47 \mathrm{mg}(75 \%) .{ }^{1} \mathrm{H} \mathrm{NMR}\left(400 \mathrm{MHz}, \mathrm{CDCl}_{3}\right) \delta 0.89(\mathrm{t}, J=6.7 \mathrm{~Hz}, 3 \mathrm{H}), 1.26(\mathrm{~s}, 28 \mathrm{H})$, $1.69(\mathrm{~m}, 2 \mathrm{H}), 2.32(\mathrm{~m}, 2 \mathrm{H}), 2.94(\mathrm{~s}, 12 \mathrm{H}), 3.96(\mathrm{~s}, 4 \mathrm{H}), 7.00(\mathrm{~s}, 2 \mathrm{H}), 7.09(\mathrm{~s}, 1 \mathrm{H}) .{ }^{13} \mathrm{C}$ NMR $\left(101 \mathrm{MHz}, \mathrm{CDCl}_{3}\right) \delta 14.1,22.7,25,6,29.4,29.6,29.7,31.9,37.8,53.2,74.5,112.4,127.5$, 135.13, 145.2, 176.8. IR (v, $\mathrm{cm}^{-1}$ ): 2916, 2848, 1658, 1546, 1462, 1440, 1055, 1033, 866. ESI-HRMS (m/z): found: $579.2736\left(\mathrm{M}-\mathrm{Cl}^{-}\right.$) (calc for $\mathrm{C}_{30} \mathrm{H}_{54} \mathrm{~N}_{3} \mathrm{OPd}$ : 579.1893).

7ba': Following procedure D with $\mathrm{Hg}(\mathrm{OAc})_{2}$ (104 mg, $0.33 \mathrm{mmol}$ ) and 6ba' (145 mg, $0.33 \mathrm{mmol}$ ) Yield: $150 \mathrm{mg}$ (67\%); then Pd(OAc) 2 (49 mg, $0.22 \mathrm{mmol}$ ) to afford $7 \mathbf{b a}$ '. Yield: $96 \mathrm{mg}$ (74\%). ${ }^{1} \mathrm{H}$ NMR (400 MHz, $\left.\mathrm{CDCl}_{3}\right) \delta 0.88(\mathrm{t}, J=6.5 \mathrm{~Hz}, 3 \mathrm{H}), 1.25(\mathrm{~s}, 24 \mathrm{H})$, $1.68(\mathrm{~m}, 2 \mathrm{H}), 2.33(\mathrm{t}, J=7.4 \mathrm{~Hz}, 2 \mathrm{H}), 2.91(\mathrm{~s}, 12 \mathrm{H}), 3.94(\mathrm{~s}, 4 \mathrm{H}), 7.02(\mathrm{~s}, 2 \mathrm{H}), 7.31(\mathrm{~s}, 1 \mathrm{H})$. ${ }^{13} \mathrm{C}$ NMR $\left(101 \mathrm{MHz}, \mathrm{CDCl}_{3}\right) \delta 14.1,22.7,25.7,29.3,29.61,29.64,31.9,37.7,53.1,74.4$, 112.5, 135.3, 145.1, 151.8, 171.5. IR (v, $\mathrm{cm}^{-1}$ ): 2980, 2924, 2853, 1659, 1597, 1540, 1452, 1380, 1258, 1149, 1069, 1019, 868, 721. ESI-HRMS (m/z): found: 550.3025 (M-Cl-) (calc for $\mathrm{C}_{28} \mathrm{H}_{50} \mathrm{~N}_{3} \mathrm{OPd}$ : 550.2989).

7ad': Following procedure D with $\mathrm{Hg}(\mathrm{OAc})_{2}(68.0 \mathrm{mg}, 0.22 \mathrm{mmol})$ and 6ad' (100 mg, $0.22 \mathrm{mmol}$ ). Palladation was carried out on the mercurated compound ( $80 \mathrm{mg}, 0.11$ $\mathrm{mmol})$ and $\mathrm{Pd}(\mathrm{OAc})_{2}(18.2 \mathrm{mg}, 0.11 \mathrm{mmol})$. Product 7ad' was purified by recrystallization in diethylether. Yield: $20 \mathrm{mg}$ (30\%). ${ }^{1} \mathrm{H}$ NMR (400 MHz, MeOD) $\delta 0.89$ (t, J = 6.9 Hz, $3 \mathrm{H}), 1.28(\mathrm{~m}, 24 \mathrm{H}), 1.68(\mathrm{~m}, 2 \mathrm{H}), 2.41(\mathrm{~m}, 2 \mathrm{H}), 2.82(\mathrm{~m}, 2 \mathrm{H}), 2.99(\mathrm{~s}, 3 \mathrm{H}$,$) ,$ $3.02(\mathrm{~s}, 3 \mathrm{H}), 3.16(\mathrm{~m}, 2 \mathrm{H}), 3.96(\mathrm{dd}, J=15.3,7.2 \mathrm{~Hz}, 2 \mathrm{H}), 4.24(\mathrm{~m}, 2 \mathrm{H}), 4.30(\mathrm{~m}, 2 \mathrm{H}), 4.50$ (d, $J=15.3 \mathrm{~Hz}, 2 \mathrm{H}), 7.13$ (s, $2 \mathrm{H}) .{ }^{13} \mathrm{C}$ NMR (101 MHz, MeOD) 13.5, 17.3, 22.4, 23.2, 25.9, 28.95, 29.03, 29.1, 29.3, 31.6, 36.9, 47.4, 47.6, 52.0, 52.1, 57.2, 60.7, 64.4, 72.1, 145.6, 145.8, 173.8, 180.0. IR (u, $\mathrm{cm}^{-1}$ ): 3295, 2920, 2849, 1655, 1598, 1547, 1451, 1123, 1072, 1049, 840. ESI-HRMS (m/z): found: $554.2283\left(\mathrm{M}-\mathrm{Cl}^{-}\right.$) (calc for $\mathrm{C}_{26} \mathrm{H}_{45} \mathrm{~N}_{3} \mathrm{O}_{3} \mathrm{Pd}$ : 554.0917).

7cd': Following procedure D with $\mathrm{Hg}(\mathrm{OAc})_{2}(120 \mathrm{mg}, 0.37 \mathrm{mmol})$ and 6cd' (200 mg, $0.37 \mathrm{mmol}$ ). Palladation was carried out on the mercurated compound (121 mg, 0.18 $\mathrm{mmol})$ and $\mathrm{Pd}(\mathrm{OAc})_{2}(34 \mathrm{mg}, 0.18 \mathrm{mmol})$ as above to afford 7cd'. Yield: $50 \mathrm{mg}(20 \%) .{ }^{1} \mathrm{H}$ NMR (300 MHz, MeOD) $\delta 0.88$ (t, J = 7.5 Hz, 3 H), 1.26 (s, 28 H), 1.67 (m, 2 H), 2.38 (s, 2 H), $2.81(\mathrm{~m}, 2 \mathrm{H}), 2.97(\mathrm{~s}, 3 \mathrm{H}), 3.00(\mathrm{~s}, 3 \mathrm{H}), 3.12(\mathrm{~m}, 2 \mathrm{H}), 3.96(\mathrm{dd}, J=15.2$ and $7.9 \mathrm{~Hz}, 2$ $\mathrm{H}), 4.21(\mathrm{~m}, 2 \mathrm{H}), 4.31(\mathrm{~m}, 2 \mathrm{H}), 4.49(\mathrm{~d}, J=15.59 \mathrm{~Hz}, 2 \mathrm{H}), 7.07(\mathrm{~d}, J=2.6 \mathrm{~Hz}, 2 \mathrm{H}) .{ }^{13} \mathrm{C}$ NMR (101 MHz, MeOD) $\delta$ 19.3, 22.1, 23.2, 27.0, 27.1, 27.2, 27.3, 27.5, 27.6, 30.3, 36.2, 
$54.2,60.7,64.4,80.3,125.5,153.1,164.2,170.5,197.0$. IR (u, $\left.\mathrm{cm}^{-1}\right): 3300,2918,2835$, 1644, 1610, 1544, 1450, 1123, 1078, 1023, 877, 657. ESI-HRMS (m/z): found: 638.3544 (M-Cl-) (calc for $\mathrm{C}_{32} \mathrm{H}_{58} \mathrm{~N}_{3} \mathrm{O}_{3} \mathrm{Pd}: 638.3520$ ).

7bd': Following procedure D with $\mathrm{Hg}(\mathrm{OAc})_{2}$ (124 mg, $\left.0.39 \mathrm{mmol}\right)$ and 6bd' (200 mg, $0.39 \mathrm{mmol}$ ). Palladation was carried out on the mercurated compound (129 mg, 0.20 $\mathrm{mmol})$ and $\mathrm{Pd}(\mathrm{OAc})_{2}(36.4 \mathrm{mg}, 0.20 \mathrm{mmol})$ as above to afford 7bd'. Yield: $50 \mathrm{mg}$ (38 \%). ${ }^{1} \mathrm{H}$ NMR (400 MHz, MeOD) $\delta 0.87(\mathrm{t}, J=6.7 \mathrm{~Hz}, 3 \mathrm{H}), 1.25(\mathrm{~m}, 24 \mathrm{H}), 1.58(\mathrm{~m}, 2 \mathrm{H}), 2.38(\mathrm{t}$, $J=7.5 \mathrm{~Hz}, 2 \mathrm{H}$ ), 2.83 (td, $J=11.4$ and $5.9 \mathrm{~Hz}, 2 \mathrm{H}$ ), $3.01(\mathrm{~s}, 3 \mathrm{H}), 2.98(\mathrm{~s}, 3 \mathrm{H}), 3.10-3.21$ (m, $2 \mathrm{H}$ ), 3.97 (dd, $J=15.6$ and $10.1 \mathrm{~Hz}, 2 \mathrm{H}$ ), 4.12 - 4.24 (m, $2 \mathrm{H}), 4.24$ - 4.39 (m, $2 \mathrm{H}), 4.49$ (d, $J=15.6 \mathrm{~Hz}, 2 \mathrm{H}), 7.13$ (d, $J=4.4 \mathrm{~Hz}, 2 \mathrm{H}) .{ }^{13} \mathrm{C}$ NMR (101 MHz, MeOD) 14.6, 23.7, 27.1, 30.4, 30.5, 30.6, 30.7, 33.1, 38.2, 53.2, 62.2, 62.3, 66.1, 73.4, 73.5, 113.8, 113.9, 137.0, 147.1, 147.3, 151.3, 174.9. IR (v, $\left.\mathrm{cm}^{-1}\right): 3350,2918,2849,1670,1620,1544,1464,1123,1077$, 1028, 880, 747. ESI-HRMS (m/z): found: 610.2838 (M-Cl-) (calc. for $\mathrm{C}_{30} \mathrm{H}_{53} \mathrm{~N}_{3} \mathrm{O}_{3} \mathrm{Pd}$ : 610.1880).

7bb': Following procedure D with $\mathrm{Hg}(\mathrm{OAc})_{2}(202 \mathrm{mg}, 0.63 \mathrm{mmol})$ and 6bb' (300 mg, $0.63 \mathrm{mmol}$ ). Yield: $450 \mathrm{mg}$ (quantitative); then $\mathrm{Pd}(\mathrm{OAc})_{2}(142 \mathrm{mg}, 0.63 \mathrm{mmol}$ ). Product 7bb'was purified by flash chromatography (DCM/EtOH 24/1). Yield: $330 \mathrm{mg}$ (85\%). ${ }^{1} \mathrm{H}$ NMR (400 MHz, $\left.\mathrm{CDCl}_{3}\right) \delta 0.87\left(\mathrm{t}, J=6.9 \mathrm{~Hz}, 3 \mathrm{H}, 1^{\text {st }}\right.$ and $2^{\text {nd }}$ diastereomers $), 1.25(\mathrm{~s}, 24 \mathrm{H}$, $1^{\text {st }}$ and $2^{\text {nd }}$ diastereomers), $1.56\left(\mathrm{t}, J=7.1 \mathrm{~Hz}, 3 \mathrm{H}, 1^{\text {st }}\right.$ diastereomer), $1.55(\mathrm{t}, J=7.1 \mathrm{~Hz}$, $3 \mathrm{H}, 2^{\text {nd }}$ diastereomer), $1.67\left(\mathrm{~m}, 2 \mathrm{H}, 1^{\text {st }}\right.$ and $2^{\text {nd }}$ diastereomers $), 2.31\left(\mathrm{t}, J=7.5 \mathrm{~Hz}, 2 \mathrm{H}, 1^{\text {st }}\right.$ and $2^{\text {nd }}$ diastereomers), $2.53\left(\mathrm{~m}, 1 \mathrm{H}, 1^{\text {st }}\right.$ diastereomer $), 2.60\left(\mathrm{~m}, 1 \mathrm{H}, 2^{\text {nd }}\right.$ diastereomer $)$, $2.96\left(\mathrm{~s}, 3 \mathrm{H}, 2^{\text {nd }}\right.$ diastereomer), $3.00\left(\mathrm{~s}, 3 \mathrm{H}, 1^{\text {st }}\right.$ diastereomer), $3.11(\mathrm{dq}, J=14.4,7.2 \mathrm{~Hz}$, $1 \mathrm{H}, 2^{\text {nd }}$ diastereomer), $3.22\left(\mathrm{dq}, J=14.4\right.$ and7.2 $\mathrm{Hz}, 1 \mathrm{H}, 1^{\text {st }}$ diastereomer $), 3.69(\mathrm{~d}, J=$ $15.5 \mathrm{~Hz}, 1 \mathrm{H}, 1^{\text {st }}$ diastereomer), $3.73\left(\mathrm{~d}, J=15.3 \mathrm{~Hz}, 1 \mathrm{H}, 2^{\text {nd }}\right.$ diastereomer $), 4.13(\mathrm{~d}, J=$ $15.4 \mathrm{~Hz}, 1 \mathrm{H}, 2^{\text {nd }}$ diastereomer), $4.18\left(\mathrm{~d}, J=15.6 \mathrm{~Hz}, 1 \mathrm{H}, 1^{\text {st }}\right.$ diastereomer $), 6.99\left(\mathrm{~s}, 1 \mathrm{H}, 1^{\text {st }}\right.$ diastereomer), $7.00\left(\mathrm{~s}, 1 \mathrm{H}, 2^{\text {nd }}\right.$ diastereomer), $7.37\left(\mathrm{~s}, 1 \mathrm{H}, 1^{\text {st }}\right.$ diastereomer $), 7.39(\mathrm{~s}, 1 \mathrm{H}$, $2^{\text {nd }}$ diastereomer). $\left.{ }^{13} \mathrm{C} \mathrm{NMR} \mathrm{(101} \mathrm{MHz}, \mathrm{CDCl}_{3}\right) \delta 13.6$ (1 $1^{\text {st }}$ diastereomer $), 13.8\left(2^{\text {nd }}\right.$ diastereomer), 14.2 ( $1^{\text {st }}$ and $2^{\text {nd }}$ diastereomers), 22.8, 25.8, 29.39, 29.45, 29.52, 29.60, $29.75,29.77,32.01$ ( $1^{\text {st }}$ and $2^{\text {nd }}$ diastereomers $), 37.8$ (1 $1^{\text {st }}$ and $2^{\text {nd }}$ diastereomers $), 52.1$ ( $2^{\text {nd }}$ diastereomer $), 52.2$ ( $1^{\text {st }}$ diastereomer $), 58.2$ ( $1^{\text {st }}$ diastereomer $), 58.4 \quad\left(2^{\text {nd }}\right.$ diastereomer $), \quad 70.4 \quad\left(1^{\text {st }}\right.$ diastereomer $), 70.8 \quad\left(2^{\text {nd }}\right.$ diastereomer $), \quad 112.0 \quad\left(1^{\text {st }}\right.$ diastereomer), 112.2 ( $2^{\text {nd }}$ diastereomer) $135.2,146.0$ ( $2^{\text {nd }}$ diastereomer $), 146.2$ ( $1^{\text {st }}$ diastereomer), 150.2 ( $1^{\text {st }}$ diastereomer $), 150.4$ ( $2^{\text {nd }}$ diastereomer $), 171.6\left(1^{\text {st }}\right.$ and $2^{\text {nd }}$ 
diastereomers). IR ( $\left.\mathrm{v}, \mathrm{cm}^{-1}\right): 2924,2853,1659,1601,1540,1452,1384,1258,1147$, 1072, 1019, 869, 717. ESI-HRMS (m/z): found: $730.3936\left(\mathrm{M}-\mathrm{Cl}-\right.$ ) (calc. for $\mathrm{C}_{42} \mathrm{H}_{62} \mathrm{~N}_{3} \mathrm{OPd}$ : 730.3928).

7bc': Following procedure D with $\mathrm{Hg}(\mathrm{OAc})_{2}$ (198 mg, $0.62 \mathrm{mmol}$ ) and 6bc' (398 mg, 0.62 mmol). Yield: $331 \mathrm{mg}(62 \%)$; then $\mathrm{Pd}(\mathrm{OAc})_{2}(86 \mathrm{mg}, 0.38 \mathrm{mmol})$ as above to afford $7 \mathbf{b c}$. Yield: $259 \mathrm{mg}(89 \%) .{ }^{1} \mathrm{H}$ NMR $\left(600 \mathrm{MHz}, \mathrm{CDCl}_{3}\right) \delta 0.88\left(\mathrm{t}, J=6.7 \mathrm{~Hz}, 3 \mathrm{H}, 1^{\text {st }}\right.$ and $2^{\text {nd }}$ diastereomers), $1.26\left(\mathrm{~s}, 24 \mathrm{H}, 1^{\text {st }}\right.$ and $2^{\text {nd }}$ diastereomers $), 1.61\left(\mathrm{t}, J=6.8 \mathrm{~Hz}, 3 \mathrm{H}, 1^{\text {st }}\right.$ diastereomer), $1.65\left(\mathrm{~m}, 2 \mathrm{H}, 1^{\text {st }}\right.$ and $2^{\text {nd }}$ diastereomers $), 1.69\left(\mathrm{t}, J=6.8 \mathrm{~Hz}, 3 \mathrm{H}, 2^{\text {nd }}\right.$ diastereomer $), 2.25\left(\mathrm{~m}, 1 \mathrm{H}, 1^{\text {st }}\right.$ and $2^{\text {nd }}$ diastereomers $), 2.40\left(\mathrm{~m}, 1 \mathrm{H}, 1^{\text {st }}\right.$ and $2^{\text {nd }}$ diastereomers), $2.67\left(\mathrm{~m}, 1 \mathrm{H}, 2^{\text {nd }}\right.$ diastereomer), $2.72\left(\mathrm{~m}, 1 \mathrm{H}, 1^{\text {st }}\right.$ diastereomer), $3.41(\mathrm{~m}$, $1 \mathrm{H}, 2^{\text {nd }}$ diastereomer $), 3.47\left(\mathrm{~m}, 1 \mathrm{H}, 1^{\text {st }}\right.$ diastereomer $), 3.63\left(\mathrm{~d}, J=15.7 \mathrm{~Hz}, 1 \mathrm{H}, 1^{\text {st }}\right.$ diastereomer), $3.75\left(\mathrm{~d}, J=15.7 \mathrm{~Hz}, 1 \mathrm{H}, 2^{\text {nd }}\right.$ diastereomer $), 3.93\left(\mathrm{~d}, J=12.7 \mathrm{~Hz}, 1 \mathrm{H}, 1^{\text {st }}\right.$ diastereomer), $4.12\left(\mathrm{~d}, J=13.0 \mathrm{~Hz}, 1 \mathrm{H}, 2^{\text {nd }}\right.$ diastereomer), $4.16\left(\mathrm{~d}, J=16.1 \mathrm{~Hz}, 1 \mathrm{H}, 2^{\text {nd }}\right.$ diastereomer), $4.26\left(\mathrm{~d}, J=15.9 \mathrm{~Hz}, 1 \mathrm{H}, 1^{\text {st }}\right.$ diastereomer $), 4.70\left(\mathrm{~d}, J=13.0 \mathrm{~Hz}, 1 \mathrm{H}, 2^{\text {nd }}\right.$ diastereomer), $4.78\left(\mathrm{~d}, J=12.7 \mathrm{~Hz}, 1 \mathrm{H}, 1^{\text {st }}\right.$ diastereomer $), 6.80\left(\mathrm{~s}, 1 \mathrm{H}, 1^{\text {st }}\right.$ diastereomer $)$, $6.81\left(\mathrm{~s}, 1 \mathrm{H}, 2^{\text {nd }}\right.$ diastereomer), $7.33\left(\mathrm{~m}, 8 \mathrm{H}, 1^{\text {st }}\right.$ and $2^{\text {nd }}$ diastereomers $), 7.72\left(\mathrm{~s}, 1 \mathrm{H}, 1^{\text {st }}\right.$ or $2^{\text {nd }}$ diastereomer), $7.86\left(\mathrm{~d}, J=6.6 \mathrm{~Hz}, 1 \mathrm{H}, 1^{\text {st }}\right.$ or $2^{\text {nd }}$ diastereomers $) .{ }^{13} \mathrm{C}$ NMR $(101 \mathrm{MHz}$, $\left.\mathrm{CDCl}_{3}\right) \quad \delta \quad 14.2 \quad\left(1^{\text {st }}\right.$ and $2^{\text {nd }}$ diastereomers $), 14.5 \quad\left(1^{\text {st }}\right.$ diastereomer $), 14.6 \quad\left(2^{\text {nd }}\right.$ diastereomer), 22.8 ( $1^{\text {st }}$ and $2^{\text {nd }}$ diastereomers), 25.8 ( $1^{\text {st }}$ and $2^{\text {nd }}$ diastereomers $), 29.4$, $29.4,29.4,29.4,29.5,29.5,29.6,29.7,29.7,29.7,29.8,29.8,29.8,32.0\left(1^{\text {st }}\right.$ and $2^{\text {nd }}$ diastereomers $), 37.8$ ( $1^{\text {st }}$ and $2^{\text {nd }}$ diastereomers $), 56.5$ ( $2^{\text {nd }}$ diastereomer $), 57.5$ ( $1^{\text {st }}$ diastereomer), 64.9 ( $1^{\text {st }}$ and $2^{\text {nd }}$ diastereomers $), 65.4$ ( $1^{\text {st }}$ diastereomer $), 65.6$ ( $2^{\text {nd }}$ diastereomer), 111.0 and $111.2\left(1^{\text {st }}\right.$ and $2^{\text {nd }}$ diastereomers $), 128.3$ ( $1^{\text {st }}$ and $2^{\text {nd }}$ diastereomers), 128.6 and 128.7 ( $1^{\text {st }}$ and $2^{\text {nd }}$ diastereomers $), 132.2$ and $132.3\left(1^{\text {st }}\right.$ and $2^{\text {nd }}$ diastereomers$), 133.7$ and 134.0 ( $1^{\text {st }}$ and $2^{\text {nd }}$ diastereomers $), 134.9$ ( $1^{\text {st }}$ and $2^{\text {nd }}$ diastereomers), 146.1 and 146.4 ( $1^{\text {st }}$ and $2^{\text {nd }}$ diastereomers $), 150.0$ and $150.4\left(1^{\text {st }}\right.$ and $2^{\text {nd }}$ diastereomers), 171.3 ( $1^{\text {st }}$ and $2^{\text {nd }}$ diastereomers). IR ( $\left.v, \mathrm{~cm}^{-1}\right): 2924,2853,1658$, 1597, 1542, 1495, 1453, 1417, 1201, 1115, 1067, 799, 749. ESI-HRMS (m/z): found: $578.3305\left(\mathrm{M}-\mathrm{Cl}^{-}\right)$(calc. for $\mathrm{C}_{30} \mathrm{H}_{54} \mathrm{~N}_{3} \mathrm{OPd}$ : 578.3308).

Synthesis of aqua complexes: Procedure E from 7ba': AgBF 4 ( $66 \mathrm{mg}, 0.34 \mathrm{mmol}$ ) was added to the solution of 7 $\mathbf{b a}$ ' (200 $\mathrm{mg}, 0.34 \mathrm{mmol}$ ) in dichloromethane $(10 \mathrm{~mL})$. The resulted mixture was stirred for $1 \mathrm{~h}$ at room temperature. The reaction was filtered 
through celite and filtrate was evaporated to afford the aqua complex as a yellow solid. Yield: $191 \mathrm{mg}$ (86 \%). ${ }^{1} \mathrm{H}$ NMR (400 MHz, $\mathrm{CDCl}_{3}$ ) $\delta 0.88$ (t, J = 6.6 Hz, 3 H), 1.25 (br. s, 24 H), 1.72 (br. s, 2 H), 2.40 (br. s, 2 H), 2.78 (br. s, 12 H), 3.89 (br. s, 4 H), 7.03 (br. s, 2 H), 8.11 (br. s, $1 \mathrm{H}) .{ }^{13} \mathrm{C}$ NMR $\left(101 \mathrm{MHz}, \mathrm{CDCl}_{3}\right) \delta$ 14.1, 22.7, 25.9, 29.3, 29.5, 29.6, 29.6, 29.7, $31.9,37.5,52.1,73.5,113.5,135.6,145.1,176.1$.

\section{Aldol condensation reaction between pivalaldehyde and tertbutylisocyanoacetate catalyzed by the metalloproteins}

B-LG (100 mg, 10\% mol) was solubilized in $20 \mathrm{mM}$ phosphate buffer $\mathrm{pH}=7.5(10 \mathrm{~mL})$. A solution of aqua complex ( $400 \mu \mathrm{L}$ of $10 \mathrm{mM}$ in $\mathrm{MeOH}, 10 \% \mathrm{~mol})$ was added and the mixture was stirred for $1 \mathrm{~h}$ at room temperature. Pivalaldehyde ( $5 \mathrm{mg}, 50 \mu \mathrm{mol}$ ) and tertbutylisocyanoacetate ( $4 \mathrm{mg}, 40 \mu \mathrm{mol}$ ) were added and the mixture was stirred for up to $72 \mathrm{~h}$ at room temperature. The aqueous solution was extracted with diisopropylether $(2 \times 9 \mathrm{~mL})$. The organic phase was evaporated to dryness, the residue was dissolved in hexane/isopropanol 1:1 (150 $\mu \mathrm{l})$ and analyzed by chiral HPLC (Kromasil 5-cellucoat, hexane/isopropanol 98/2 for $19 \mathrm{~min}$ then to $96 / 4$ in $11 \mathrm{~min}$ at $1 \mathrm{ml} / \mathrm{min}$, detection at $215 \mathrm{~nm}$ ) to determine the diastereomeric and the enantiomeric ratios.

\section{Aldol condensation reaction between benzaldehyde and methylisocyanoacetate catalyzed by the metalloproteins}

B-LG (10 mg, 15\% mol) was solubilized in $20 \mathrm{mM}$ phosphate buffer $\mathrm{pH}=7.5(0.5 \mathrm{~mL})$. A solution of aqua complex ( $25 \mu \mathrm{L}$ of $10 \mathrm{mM}$ solution in $\mathrm{MeOH}, 10 \% \mathrm{~mol}$ ) was added and the mixture was stirred for $1 \mathrm{~h}$ at room temperature. Benzaldehyde $(25 \mu \mathrm{L}$ of $100 \mathrm{mM}$ in DMSO, $2.5 \mu \mathrm{mol}$ ) and methylisocyanoacetate (30 $\mu \mathrm{L}$ of $100 \mathrm{mM}$ solution in DMSO, 3 $\mu \mathrm{mol})$ were added and the mixture was stirred at room temperature. Aliquots (50 $\mu \mathrm{L})$ of the reaction mixture were taken each $15 \mathrm{~min}$, diluted in $950 \mu \mathrm{L}$ water and submitted to RP-HPLC analysis under isocratic conditions (Nucleosil C18 Htec 150 x 4.6 mm, 40\% $\mathrm{MeCN}$ in $\mathrm{H}_{2} \mathrm{O}$ at $1 \mathrm{ml} / \mathrm{min}$, detection at $254 \mathrm{~nm}$ ). After $3 \mathrm{~h} 30$, the reaction medium was analyzed by RP-HPLC under gradient conditions (Nucleosil C18 Htec 150 x $4.6 \mathrm{~mm}, 5$ to $100 \% \mathrm{MeCN}$ in $\mathrm{H}_{2} \mathrm{O}$ in $40 \mathrm{~min}$ at $1 \mathrm{ml} / \mathrm{min}$, detection at $254 \mathrm{~nm}$ ) to determine the d.r.. Then the aqueous solution was extracted with diisopropylether $(2 \times 0.9 \mathrm{ml})$. The organic phase evaporated to dryness, the residue dissolved in hexane/isopropanol 1:1 (150 $\mu \mathrm{l})$ and analyzed by chiral HPLC (Kromasil 5-cellucoat, hexane/isopropanol 98/2 for 19 min then to $96 / 4$ in $11 \mathrm{~min}$ at $1 \mathrm{ml} / \mathrm{min}$ ) to determine the enantiomeric ratio. 


\section{Acknowledgements}

This work was financially supported by the LabEx MiChem part of French state funds managed by the ANR within the Investissements d'Avenir programme under reference ANR-11-IDEX-0004-02 and by the Agence Nationale de la Recherche (project Artzymes, grant number ANR-11-BS07-027-01).

\section{Supporting information}

Details of experimental procedures, computational details, NMR and CD spectra as well as kinetic studies can be found in the supporting information.

\section{References}

[1] J. Bos, G. Roelfes, Curr. Op. Chem. Biol. 2014, 19, 135-143.

[2] M. E. Wilson, G. M. Whitesides, J. Am. Chem. Soc. 1978, 100, 306-307.

[3] a) J. Steinreiber, T. R. Ward, Coord. Chem. Rev. 2008, 252, 751-766; b) F. Rosati, G. Roelfes, ChemCatChem 2010, 2, 916-927; c) I. D. Petrik, J. Liu, Y. Lu, Curr. Op. Chem. Biol. 2014, 19, 67-75.

[4] a) M. Durrenberger, T. R. Ward, Curr. Op. Chem. Biol. 2014, 19, 99-106; b) J. C. Lewis, ACS Catal. 2013, 3, 2954-2975.

[5] a) C. Letondor, N. Humbert, T. R. Ward, Proc. Natl. Acad. Sci. USA 2005, 102, 4683-4887; b) F. W. Monnard, E. S. Nogueira, T. Heinisch, T. Schirmer, T. R. Ward, Chem. Sci. 2013, 4, 3269-3274; c) M. Skander, N. Humbert, J. Collot, J. Gradinaru, G. Klein, A. Loosli, J. Sauser, A. Zocchi, F. Gilardoni, T. R. Ward, J. Am. Chem. Soc. 2004, 126, 14411-14418; d) M. Pellizzoni, G. Facchetti, R. Gandolfi, M. Fuse, A. Contini, I. Rimoldi, Chemcatchem 2016, 8, 1665-1670.

[6] M. Allard, C. Dupont, V. Munoz Robles, N. Doucet, A. Lledos, J.-D. Maréchal, A. Urvoas, J.-P. Mahy, R. Ricoux, ChemBioChem 2012, 13, 240-251.

[7] a) A. Pordea, M. Creus, J. Panek, C. Duboc, D. Mathis, M. Novic, T. R. Ward, J. Am. Chem. Soc. 2008, 130, 8085-8088; b) A. Pordea, D. Mathis, T. R. Ward, J. Organomet. Chem. 2009, 694, 930-936; c) R. Ricoux, M. Allard, R. Dubuc, C. Dupont, J. D. Marechal, J. P. Mahy, Org. Biomol. Chem. 2009, 7, 3208-3211; d) L. Rondot, E. Girgenti, F. Oddon, C. Marchi-Delapierre, A. Jorge-Robin, S. Menage, J. Mol. Cat. A-Chem. 2016, 416, 20-28; e) J. Tang, F. P. Huang, Y. Wei, H. D. Bian, W. Zhang, H. Liang, Dalton Trans. 2016, 45, 8061-8072; f) J. L. Zhang, D. K. Garner, L. Liang, D. A. Barrios, Y. Lu, Chem. Eur. J. 2009, 15, 7481-7489; g) J. L. Zhang, D. K. Garner, L. Liang, Q. Chen, Y. Lu, Chem. Comm. 2008, 1665-1667.

[8] T. K. Hyster, L. Knorr, T. R. Ward, T. Rovis, Science 2012, 338, 500-503.

[9] a) R. P. Megens, G. Roelfes, Chem. Commun. 2012, 48, 6366-6368; b) D. Coquiere, J. Bos, J. Beld, G. Roelfes, Angew. Chem. Int. Ed. 2009, 48, 51595162; c) Y. Li, C. Wang, G. Jia, S. Lu, C. Li, Tetrahedron 2013, 69, 65856590. 
[10] a) P. J. Deuss, G. Popa, A. M. Z. Slawin, W. Laan, P. C. J. Kamer, ChemCatChem 2013, 5, 1184 - 1191; b) J. Bos, F. Fusetti, A. J. M. Driessen, G. Roelfes, Angew. Chem. Int. Ed. 2012, 51, 7472-7475; c) W. Ghattas, L. Cotchico-Alonso, J. D. Marechal, A. Urvoas, M. Rousseau, J. P. Mahy, R. Ricoux, Chembiochem 2016, 17, 433-440; d) T. Himiyama, D. F. Sauer, A. Onoda, T. P. Spaniol, J. Okuda, T. Hayashi, J. Inorg. Biochem. 2016, 158, 5561.

[11] V. Munoz Robles, E. Ortega-Carrasco, L. Alonso-Cotchico, J. RodriguezGuerra, A. Lledos, J.-D. Marechal, ACS Catal. 2015, 5, 2469-2480.

[12] P. J. Deuss, R. den Heeten, W. Laan, P. C. J. Kamer, Chem. Eur. J. 2011, 17, 4680-4698.

[13] a) A. Chevalley, M. V. Cherrier, J. C. Fontecilla-Camps, M. Ghasemi, M. Salmain, Dalton Trans. 2014, 43, 5482 - 5489; b) A. Chevalley, M. Salmain, Chem. Commun. 2012, 48, 11984-11986.

[14] a) C. A. Kruithof, M. A. Casado, G. Guillena, M. R. Egmond, A. van de Kerkvan Hoof, A. J. R. Heck, R. J. M. Klein Gebbink, G. van Koten, Chem. Eur. J. 2005, 11, 6869-6877; b) C. A. Kruithof, H. P. Dijkstra, M. Lutz, A. L. Spek, M. R. Egmond, R. J. M. Klein Gebbink, G. van Koten, Eur. J. Inorg. Chem. 2008, 4425-4432; c) L. Rutten, B. Wieczorek, J. Mannie, C. A. Kruithof, H. P.

Dijkstra, M. R. Egmond, M. Lutz, R. Gebbink, P. Gros, G. van Koten, Chem.

Eur. J. 2009, 15, 4270-4280; d) B. Wieczorek, H. P. Dijkstra, M. R. Egmond, R. J. M. Klein Gebbink, G. van Koten, J. Organomet. Chem. 2009, 694, 812822.

[15] M. Filice, O. Romero, A. Aires, J. M. Guisan, A. Rumbero, J. M. Palomo, Adv. Synth. Catal. 2015, 357, 2687-2696.

[16] W. Laan, B. K. Munoz, R. den Heeten, P. C. J. Kamer, ChemBioChem 2010, 11, 1236-1239.

[17] S. Abe, J. Niemeyer, M. Abe, Y. Takezawa, T. Ueno, T. Hikage, G. Erker, Y. Watanabe, J. Am. Chem. Soc. 2008, 130, 10512-10514.

[18] a) J. Pierron, C. Malan, M. Creus, J. Gradinaru, I. Hafner, A. Ivanova, A. Sardo, T. R. Ward, Angew. Chem. Int. Ed. 2008, 47, 701-705; b) A. Chatterjee, H. Mallin, J. Klehr, J. Vallapurackal, A. D. Finke, L. Vera, M. Marsh, T. R. Ward, Chem. Sci. 2016, 7, 673-677.

[19] N. Selander, K. J. Szabó, Chem. Rev. 2011, 111, 2048-2076.

[20] a) J. Zheng, S. Liu, B.-W. Jiang, T. B. Marder, Z. Yang, Can. J. Chem. 2012, 90, 138-144; b) D. E. Bergbreiter, P. L. Osburn, Y.-S. Liu, J. Am. Chem. Soc. 1999, 121, 9531-9538.

[21] A. R. Katritzky, H.-Y. He, K. Suzuki, J. Org. Chem. 2000, 65, 8210.

[22] P. Steenwinkel, R. A. Gossage, G. van Koten, Chem. Eur. J. 1998, 4, 759762.

[23] B. Soro, S. Stoccoro, G. Minghetti, A. Zucca, M. A. Cinellu, S. Gladiali, M. Manassero, M. Sansoni, Organometallics 2005, 24, 53-61.

[24] A. Arnaiz, J. V. Cuevas, G. Garcia-Herbosa, A. Carbayo, J. A. Casares, E. Gutierrez-Puebla, J. Chem. Soc., Dalton Trans. 2002, 2581.

[25] C. Hawkins, J. A. Palmer, Coord. Chem. Rev. 1982, 44, 1.

[26] a) G. Kontopidis, C. Holt, L. Sawyer, J. Dairy Sci. 2004, 87, 785-796; b) S. Le Maux, S. Bouhallab, L. Gliblin, A. Brodkorb, T. Crogennec, Dairy Sci. \& Technol. 2014, 94, 409-426.

[27] A. Taheri-Kafrani, Y. Choiset, D. A. Faizullin, Y. F. Zuev, V. V. Bezuglov, J.-M. Chobert, A.-K. Bordbar, T. Haertle, Biopolymers 2011, 95, 871-880. 
[28] F. Zsila, T. Imre, P. T. Szabo, Z. Bikadi, M. Simonyi, FEBS Lett. 2002, 520, 81-87.

[29] a) O. Nicolotti, I. Giangreco, T. F. Miscioscia, A. Carotti, J. Chem. Inf. Model. 2009, 49, 2290-2302; b) O. Nicolotti, T. F. Miscioscia, A. Carotti, F. Leonetti, A. Carotti, J. Chem. Inf. Model. 2008, 48, 1211-1226; c) D. Plewczynski, M. Łaźniewski, R. Augustyniak, K. Ginalski, J. Comput. Chem. 2011, 32, 742755.

[30] M. V. Cherrier, S. Engilberge, P. Amara, A. Chevalley, M. Salmain, J. C. Fontecilla-Camps, Eur. J. Inorg. Chem. 2013, 3596-3600.

[31] A. Divsalar, A. A. Saboury, H. Mansoori-Torshizi, F. Ahmad, J. Phys. Chem. B 2010, 114, 3639-3647.

[32] a) H. P. Dijkstra, M. Q. Slagt, A. McDonald, C. A. Kruithof, R. Kreiter, A. M. Mills, M. Lutz, A. L. Spek, W. Klopper, G. P. M. van Klink, G. van Koten, Eur. J. Inorg. Chem. 2003, 830-838; b) G. Guillena, G. Rodriguez, G. van Koten, Tetrahedron Lett. 2002, 43, 3895-3898; c) N. C. Mehendale, C. Bezemer, C. A. van Walree, R. Gebbink, G. van Koten, J. Mol. Cat. A 2006, 257, 167-175; d) M. Q. Slagt, D. A. P. van Zwieten, A. Moerkerk, R. Gebbink, G. van Koten, Coord. Chem. Rev. 2004, 248, 2275-2282; e) B. Soro, S. Stoccoro, G. Minghetti, A. Zucca, M. A. Cinellu, M. Manassero, S. Gladiali, Inorg. Chim. Acta 2006, 359, 1879-1888; f) R. van de Coevering, M. Kuil, R. Gebbink, G. van Koten, Chem. Commun. 2002, 1636-1637; g) S. Gosiewska, S. Herreras Martinez, M. Lutz, A. L. Spek, G. van Koten, R. J. M. Klein Gebbink, Eur. J. Inorg. Chem. 2006, 4600-3607; h) S. Gosiewska, S. Martinez Herreras, M. Lutz, A. L. Spek, R. W. A. Havenith, G. P. M. van Klink, G. van Koten, R. J. M. Klein Gebbink, Organometallics 2008, 27, 2549-2559.

[33] D. M. Grove, G. Van Koten, J. N. Louwen, J. G. Noltes, A. L. Spek, H. J. C. Ubbels, J. Am. Chem. Soc. 1982, 104, 6609-6616.

[34] A. R. Katritzky, H.-Y. He, K. Suzuki, J. Org. Chem. 2000, 65, 8210-8213. 


\section{Table of contents}

Artificial metalloenzymes

Prochiral NCN-pincer palladium(II) complexes of hemilabile ligands carrying a long aliphatic chain were shown to insert within bovine oflactoglobin as assessed by CD spectroscopy and molecular docking calculations. Adjunction of H-bond donor substituents gave more stable supramolecular assemblies. These constructs catalyzed aldol condensations affording in some cases the less favorable cis-product.

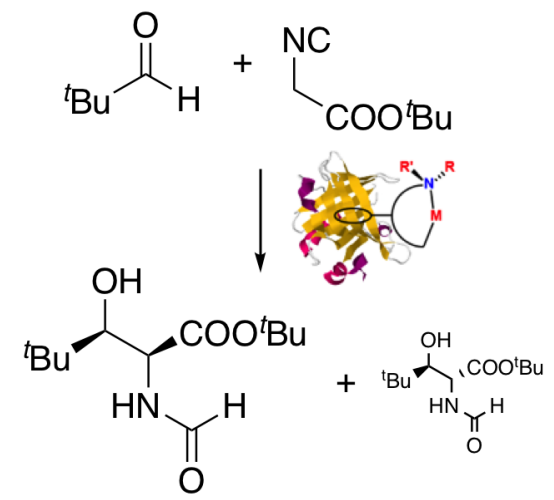

